\title{
A three generation family study of cleft lip with or without cleft palate
}

\author{
C O CARTER, KATHLEEN EVANS, REBECCA COFFEY, AND \\ J A FRASER ROBERTS, ANNIS BUCK, MARGARET FRASER ROBERTS
}

From the MRC Clinical Genetics Unit, Institute of Child Health, 30 Guilford Street, London WC1N 1EH

SUMMARY A family study of cleft lip, with or without cleft palate, was based on those treated by operation at The Hospital for Sick Children, London, between 1920 and 1939 in order to give information on the proportion affected of children and grandchildren. The probands were those who had survived, were successfully traced, and found to have had at least one child. Care was taken to exclude patients who were traced through a child, whether normal or affected, and not through the usual tracing procedure. Patients with recognised syndromes were also excluded. Because the series was based on patients who had survived and reproduced it was biased in favour of those with milder degrees of the malformation, and against those with any severe associated malformation.

The proportion affected of children of probands was $3 \cdot 15 \%( \pm 0 \cdot 56)$, of sibs $2 \cdot 79 \%( \pm 0 \cdot 52)$, and of parents $1 \cdot 18 \%( \pm 0 \cdot 37)$, respectively. The lower proportion of parents affected is attributed to reduced reproductive fitness of patients born two generations ago. The proportion affected of nephews and nieces, aunts and uncles, and grandchildren was $0 \cdot 47 \%( \pm 0 \cdot 18), 0 \cdot 59 \%( \pm 0 \cdot 13)$, and $0.8 \%( \pm 0 \cdot 6)$, respectively. The proportion affected of first cousins was $0 \cdot 27 \%( \pm 0 \cdot 08)$. The birth frequency of cleft lip ( \pm cleft palate) is estimated to be about $0.1 \%$ in England. There were two first cousin and one second cousin marriages among the marriages of the parents. There was no increase of cleft palate among the relatives of the probands.

The proportion of sibs affected increased with increasing severity of the malformation in the proband, where the proband was female, and where the proband had an affected parent or already had one affected sib. It was not, however, increased where a more remote relative was affected. The proportion of children affected was not increased when the proband had an affected parent or sib, but few families provided information.

The most economical hypothesis to explain the findings is the multifactorial threshold model. The birth frequency of the malformation and the family patterns found make it improbable that one single mutant gene makes a major contribution to the liability to develop the condition.

The early and classic study of the family patterns of cleft lip and cleft palate by Fogh-Andersen ${ }^{1}$ in Denmark was a landmark for the study of the common congenital malformations.

His study based on patients admitted for operation in Copenhagen from 1934 to 1941 indicated: that cleft lip with or without cleft palate $(\mathrm{CL} \pm \mathrm{CP})$ was in most instances an entity distinct genetically from mid-line cleft palate (CP); that all degrees of $C L \pm$ CP might occur within a family; that the proportion affected of sibs of index patients was over 40 times the birth frequency (about 1.1 per 1000) in Denmark; that the proportion of aunts and uncles was about

Received for publication 12 September 1981 seven times and that of first cousins about three times the birth frequency. The author also noted that where the proband had a parent affected the risk to sibs was substantially increased, but that the presence of an affected second or third degree relative did not appreciably affect the risk of recurrence. Fogh-Andersen's series was based on child index patients and so there is no information on children or nephews and nieces. Fogh-Andersen suggested modified dominant inheritance, but considered that modified recessive inheritance was not excluded. A critical test for recessive inheritance is the proportion of children affected compared to that of sibs, and so in 1958 we began a family study of index patients treated surgically at The Hospital 
for Sick Children between 1920 and 1939. Preliminary findings of this study have been reported. ${ }^{2-6}$ In 1961 , Carter ${ }^{2}$ proposed what is usually now termed the multifactorial threshold model for both pyloric stenosis and $\mathrm{CL} \pm \mathrm{CP}$. Other large series have since been reported on European or European-derived populations, usually, like that of Fogh-Andersen, based on child probands, ${ }^{7-9}$ and in summary form by Curtis et al ${ }^{10}$ The Copenhagen series has been updated to include children of the original probands ${ }^{11}$ and a second series has been reported based on more recent Danish births. ${ }^{12}$ Japanese series are available, notably from Kyushu University, ${ }^{13}$ but there the birth frequency is greater, the proportion of sibs and children affected is less, and the male preponderance is less.

We now report in some detail our series, brought up to date, which includes 251 grandchildren as well as over 1000 children of the probands.

\section{Material and methods}

The initial series was all those children who came to The Hospital for Sick Children for repair to CL \pm CP (and CP only) between 1920 and 1939. The series was compiled by taking from the surgical registers the consecutive names of all children treated during that time, with the exception of any known to have died before the study started and any with a known syndrome of which $\mathrm{CL} \pm \mathrm{CP}$ or $\mathrm{CP}$ only is a part. Altogether the names of 715 boys and 390 girls with CL $\pm C P$ were listed as well as 245 boys and 329 girls with CP only. The CP patients are excluded from this paper, but will be reported separately.

The follow-up of these patients has taken place in two phases over more than 20 years from 1958 to 1980. Phase I was begun by JAFR and ARB in 1958 and phase II by COC, KAE, and RC in 1973 and 1978.

Using the methods described below we tried during the years 1958 to 1980 to trace all the 715 men and 390 women with $C L \pm C P$. When traced, family histories were collected at a visit to the homes of those who already had children. It is these patients who are the probands for the study. The pedigrees collected extend to the children, sibs, parents, nephews, nieces, uncles, aunts, grandchildren, and cousins of the probands.

Reports of $C L \pm C P$ in relatives were verified from medical records wherever possible or by personal examination or from photographs, or all these. If no such confirmation was possible we accepted a description by a mother of her child (maybe one who had died in infancy), or a story of an affected adult whose lesion had actually been seen by our informant. It is not therefore always possible to be precise in the description of the malformation in an affected relative. A few reports of affected relatives were not accepted because it was not possible to get confirmation of the malformation. Verification by records was successful for all affected children of probands. Stillbirths were not evaluated nor included in the count of relatives.

\section{TRACING THE PROBANDS}

Phase $I$. When the study started the oldest patients were already over the age of 40 and the youngest over the age of 20. The Hospital for Sick Children normally transfers patients to adult hospitals at $\mathbf{1 2}$ years of age, so that the last address on the records was often many years out of date. The methods of tracing were as follows.

We first wrote to the parents of all patients at the address on the medical record. If they had moved away we tried the present occupier of the house, or a family member if known, or any other possible local source. Any families traced successfully in this way we have called 'directly' traced.

The next step was an attempt to get full names and precise dates of birth from their birth certificates at Somerset House in order to try and identify them through statutory registers.

In 1958 the National Health Service Central Register at Southport was not ready for use in helping to trace patients. The Ministry of National Insurance, where there is a register of all those working and so paying National Insurance contributions, kindly agreed to post on letters to patients who could be identified with near certainty on their register. When patients received the letter the onus was on them to reply to us giving their current address. Because there was no cross-index to the maiden names of married women no attempt was made to trace those women born before 1930 because it was likely that they would have changed their names on marriage and, in addition, were probably not at work if they had young children, and so not paying National Insurance.

By 1961 the National Health Service Central Register was ready for use. The staff there, when they thought it likely that they had identified the patient, kindly informed us of the local executive committee (now family practitioner committee) with which the patients were registered. They in turn informed us of the patients' family doctors. We then wrote to the family doctors asking for the patients' current addresses and permission to ask them to take part in the study if they had had children.

By the methods described we were finally able to get the addresses of 531 men and 238 women. We then wrote to them asking if they were our patients and if they now had children. We had replies from 
530 men and 229 women. We then visited, in their own homes, the 185 men and 110 women who had already had at least one child and took a family history. Traced, but not included in the study, were 25 men and 13 women who had died, emigrated, or were in long-stay hospitals, and the five men and one woman who replied saying they were not willing to help. We were not able to trace 185 men and 161 women in this initial search and no further effort in the ensuing years was made to trace them.

Phase II. In 1973 we wrote to the probands who had had children by 1962 , asking whether they had had more children or grandchildren, but no attempt was made at that time to trace those who had moved from their 1962 address. In 1978 we again wrote to the probands to bring their families up to date. We also wrote to those traced in 1962 , but who at that time had no children. Both the last two groups were visited for family histories if children had now been born. In 1978 we also attempted to trace those who had moved between 1962 and 1973 and, if traced, wrote to them to bring their family history up to date. We excluded 60 men born before 1925 and 21 women born before 1927 who had no children in 1962 because they were unlikely to have started families since then. We also excluded those patients, with children in 1962, who were unlikely to have had more children since 1973, and whose existing children were too young to provide any grandchildren by 1978 . This most recent attempt to trace in 1978 was firstly 'direct' to the probands at their last known address, and secondly using the National Health Service Central Register. Where a proband had died or emigrated since 1962 we tried tracing through a son or daughter, again 'directly' where we had an address, or through the NHS Central Register if we knew the full name and date of birth of the son or daughter.
Where a proband had written between 1962 and 1978 with family information and a change of address, we were careful to include the children or grandchildren only if we had also traced the proband to his latest address using the NHS Central Register. Thus, no children or grandchildren, whether affected or not, have been included unless traced by the usual routine. There were three patients (each with unilateral cleft lip) who were known to have an affected child and others to have unaffected children, but these children were excluded because the patients were not traced by the usual routine.

By 1980 the total number with children traced in both phases was 278 men and 146 women and these are the probands for the family study. The numbers of those with and without children who were traced in phase $I$ and the results of our subsequent efforts to retrace them in phase II are shown in table 1 . The method by which each individual proband was traced at each stage is shown in the appendix.

CLASSIFICATION OF PROBANDS

The probands have been classified into four groups:

(I) unilateral cleft lip (CLu);

(II) bilateral cleft lip (CLb);

(III) unilateral cleft lip and palate (CLCPu); and

(IV) bilateral cleft lip and palate (CLCPb).

The large majority of probands for the family study had no other malformations. Since they were survivors, who had had at least one child, they will mostly exclude any with an associated major malformation or severe mental retardation, and those with known syndromes were already excluded. In addition those with the more severe forms of $\mathrm{CL} \pm \mathrm{CP}$ will be underrepresented, since 50 years ago many of them died before or after operation. One patient (369) was congenitally deaf. One (5) had a large naevus on the right side of his face and no

TABLE 1(a) Tracing of male probands

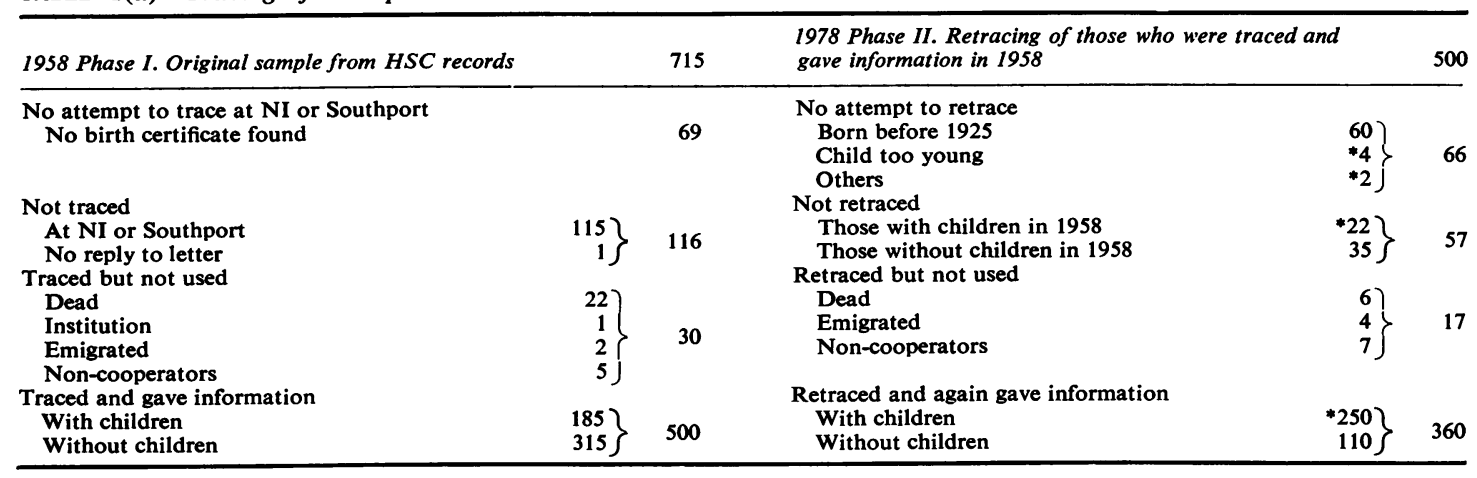

* Probands for family study. 
TABLE 1(b) Tracing of female probands

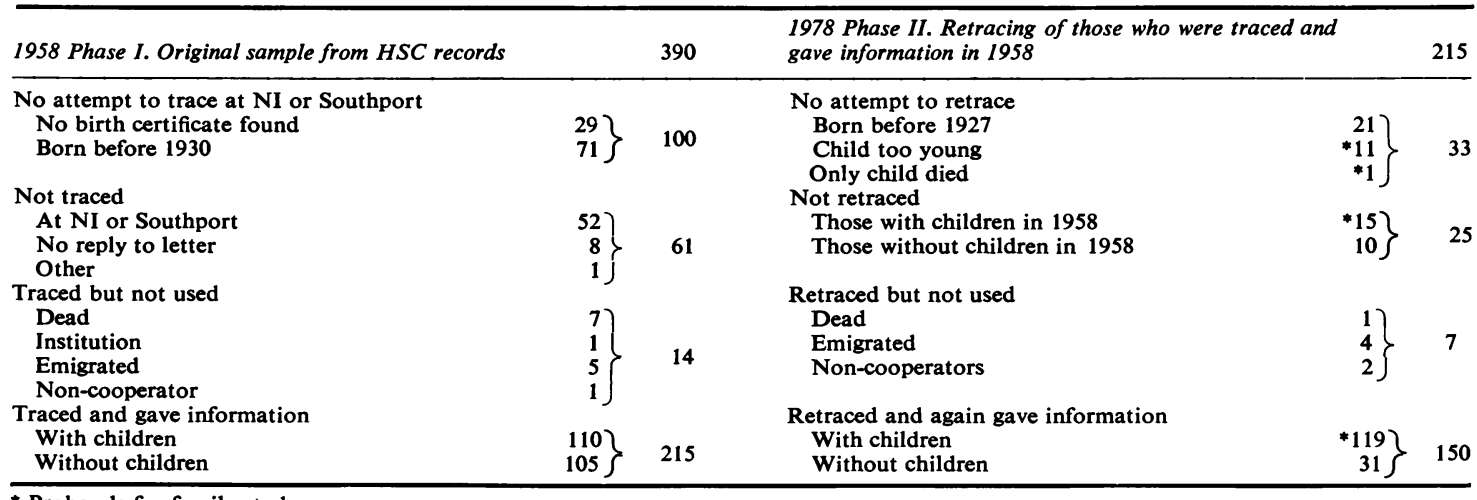

* Probands for family study.

vision in his right eye. One (83) had ulnar polydactyly of one foot, but so did two of his unaffected children. One (316) had syndactyly of the right foot and a congenital amputation of the right forefinger and the terminal phalanx of the right thumb and ring finger.

\section{Results}

The number of probands in each group was: group I 90 men and 62 women; group II three men and eight women; group III 139 men and 50 women; group IV 46 men and 26 women.

TWINS

There were eight probands who were twin born. These included one concordant pair (12 and 122) who were both probands. On examination (COC) these were almost certainly dizygotic, differing in hair colour and shape of face, nose, and fingers; they were never mistaken for each other. On examination proband 60 and his co-twin and proband 356 and her co-twin were also almost certainly dizygotic, and 277 and his co-twin were certainly dizygotic differing in physical features and Lewis, Duffy, and Kell blood groups. The twin of 264 was stillborn and there is no information on zygosity. Proband 41 was one of triplets, one of whom was still-born and sex and presence of facial cleft is not known; the other died aged 42 years of coronary heart disease. From the good description from members of the family he was probably monozygotic with 41 and often mistaken for him. These, probably the only monozygotic pair, were discordant, as were three of the four dizygotic like-sex pairs and the only unlike-sex pair. Details are shown in table 2.

FIRST DEGREE RELATIVES

The findings in sibs and children are shown in table 3.
TABLE 2 Twins

\begin{tabular}{|c|c|c|c|}
\hline \multicolumn{2}{|c|}{ Proband } & \multirow{2}{*}{$\frac{\text { Co-twin }}{\mathrm{M}}$} & \multirow{2}{*}{$\begin{array}{l}\text { Type of twinning } \\
\mathrm{DZ}\end{array}$} \\
\hline 60 & $\mathbf{M}^{*}$ & & \\
\hline $\left.\begin{array}{r}12 \\
122\end{array}\right\}$ & $\mathbf{M}^{*}$ & $\mathbf{M}^{*}$ & $\mathbf{D Z}$ \\
\hline $\begin{array}{l}264 \\
277\end{array}$ & $\begin{array}{l}\mathbf{M}^{*} \\
\mathbf{M}^{*}\end{array}$ & $\begin{array}{l}\mathbf{M} \text { (SB) } \\
\mathbf{M}\end{array}$ & $\begin{array}{l}\text { NK } \\
\text { DZ }\end{array}$ \\
\hline 3 & $\mathbf{M}^{*}$ & $\mathbf{F}$ & $\mathbf{D Z}$ \\
\hline 85 & $\mathbf{M}^{*}$ & NK (SB) & NK \\
\hline 356 & $\mathbf{F}^{*}$ & $\begin{array}{l}\mathbf{F} \\
\text { Co-triplet }\end{array}$ & $\mathbf{D Z}$ \\
\hline 41 & $\mathbf{M}^{*}$ & $\left\{\begin{array}{l}\mathrm{M} \\
\mathrm{NK}(\mathrm{SB})\end{array}\right.$ & $\begin{array}{l}\text { MZ } \\
\text { NK }\end{array}$ \\
\hline
\end{tabular}

M, male; F, female; *, proband; SB, stillborn; NK, not known.

\section{Children}

The proportion of live-born children affected was $3.15 \%( \pm 0 \cdot 56)$. Subdividing by sex of proband the proportions affected are $2.64 \%$ and $4.04 \%$ for male and female probands, respectively. One of the liveborn affected children (of proband 83) also had congenital heart malformation, another (of 365) also had renal agenesis, and another (of 212) also had pyloric stenosis. Live-born children without $\mathrm{CL} \pm \mathrm{CP}$ included three with congenital heart malformation (children of 8, 136, and 162), three with spina bifida (of 172, 217, and 303), three with club foot (of 84, 155 , and 240), one with tracheo-oesophageal fistula (of 106), one with imperforate anus (of 175), one with pyloric stenosis (of 8), and one deaf from rubella embryopathy (of 83). In addition seven children were mentally retarded including two with cerebral palsy. The probands also had 19 stillborn children including three with anencephaly (of 217 , 385 , and 392), one with spina bifida (of 119), and one with bilateral renal agenesis (of 165).

Sibs

The proportion of sibs affected using the Weinberg proband method is $2.79 \%( \pm 0.52), 3.01 \%$ for 
TABLE 3 Children and sibs of probands: numbers affected shown in brackets

\begin{tabular}{|c|c|c|c|c|c|c|c|c|c|}
\hline \multirow[t]{3}{*}{ Probands } & & \multicolumn{3}{|l|}{ Children } & \multicolumn{5}{|l|}{ Sibs } \\
\hline & & \multirow[t]{2}{*}{ Sons } & \multirow[t]{2}{*}{ Daughters } & \multirow[t]{2}{*}{ Total } & \multicolumn{2}{|l|}{ Brothers } & \multicolumn{2}{|l|}{ Sisters } & \multirow[t]{2}{*}{ Total } \\
\hline & & & & & Before & After & Before & After & \\
\hline \multirow[t]{2}{*}{$\begin{array}{l}\text { Male } \\
\text { CLu } \\
\text { CLb } \\
\text { CLCPu } \\
\text { CLCPb }\end{array}$} & $\begin{array}{r}90 \\
3 \\
139 \\
46\end{array}$ & $\begin{array}{c}99(4) \\
4(1) \\
159(5) \\
66\end{array}$ & $\begin{array}{c}117(2) \\
3 \\
161(5) \\
35\end{array}$ & $\begin{array}{c}216(6) \\
7(1) \\
320(10) \\
101\end{array}$ & $\begin{array}{c}69 \\
3 \\
96(4) \\
29(4)\end{array}$ & $\begin{array}{c}52 \\
2 \\
85(1) \\
26(2)\end{array}$ & $\begin{array}{c}69(2) \\
1 \\
94(2) \\
30(1)\end{array}$ & $\begin{array}{c}61 \\
0 \\
68(2) \\
20(2)\end{array}$ & $\begin{array}{c}251(2) \\
6 \\
343(9) \\
105(9)\end{array}$ \\
\hline & & $328(10)$ & $316(7)$ & $\begin{array}{l}644(17) \\
2.64 \%\end{array}$ & $197(8)$ & $165(3)$ & 194(5) & 149(4) & $\begin{array}{l}705(20) \\
2.84 \%\end{array}$ \\
\hline \multirow[t]{2}{*}{$\begin{array}{l}\text { Female } \\
\text { CLu } \\
\text { CLb } \\
\text { CLCPu } \\
\text { CLCPb }\end{array}$} & $\begin{array}{r}62 \\
8 \\
50 \\
26\end{array}$ & $\begin{array}{l}77(2) \\
11 \\
63(7) \\
42(4)\end{array}$ & $\begin{array}{l}73(2) \\
11 \\
65 \\
29\end{array}$ & $\begin{array}{c}150(4) \\
22 \\
128(7) \\
71(4)\end{array}$ & $\begin{array}{l}31(1) \\
6 \\
31 \\
19(2)\end{array}$ & $\begin{array}{l}33 \\
8(1) \\
27 \\
9\end{array}$ & $\begin{array}{c}29(1) \\
1 \\
36 \\
20\end{array}$ & $\begin{array}{c}33(3) \\
3(1) \\
33 \\
14\end{array}$ & $\begin{array}{c}126(5) \\
18(2) \\
127 \\
62(2)\end{array}$ \\
\hline & & 193(13) & $178(2)$ & $\begin{array}{l}371(15) \\
4.04 \%\end{array}$ & $87(3)$ & $77(1)$ & $86(1)$ & $83(4)$ & $\begin{array}{l}333(9) \\
2 \cdot 70 \%\end{array}$ \\
\hline Total & & $521(23)$ & 494(9) & $\begin{array}{r}1015(32) \\
3.15 \%\end{array}$ & $284(11)$ & 242(4) & $280(6)$ & $232(8)$ & $\begin{array}{r}1038(29) \\
2.79 \%\end{array}$ \\
\hline
\end{tabular}

CL, cleft lip alone; CLCP, cleft lip and cleft palate; u, unilateral; b, bilateral.

those born before and $2.53 \%$ for those born after the proband. Subdividing by sex of proband the proportions were 2.84 and $2.79 \%$ for male and female probands, respectively. No attempt was made to document fully other malformations in live-born sibs, but it is noteworthy that six had spina bifida cystica (sibs of 30,99, 193, 303, 318, and 385 ), and one had hydrocephalus (of 16); in addition one stillborn sib (of 99) had hydrocephalus.

Parents

The findings in parents are shown in table 4. The proportion of fathers affected was $1.65 \%( \pm 0.62)$ and of mothers $0.71 \%( \pm 0.41)$.

TABLE 4 Parents of probands: numbers affected shown in brackets

\begin{tabular}{lccc}
\hline Probands & Fathers & Mothers & All parents \\
\hline Male & & & \\
CLu & 90 & $90(1)$ & $180(1)$ \\
CLb & 3 & 3 & 6 \\
CLCPu & $139(3)$ & $139(1)$ & $278(4)$ \\
CLCPb & $46(1)$ & $46(1)$ & $92(2)$ \\
\cline { 2 - 4 } & $278(4)$ & $278(3)$ & $556(7)$ \\
\hline Female & $62(2)$ & 62 & $124(2)$ \\
CLu & 8 & 8 & 16 \\
CLb & $50(1)$ & 50 & $100(1)$ \\
CLCPu & 26 & 26 & 52 \\
CLCPb & $146(3)$ & 146 & $292(3)$ \\
\cline { 2 - 4 } & $424(7)$ & $424(3)$ & $848(10)$ \\
Total & & & $1 \cdot 18 \%$ \\
\hline
\end{tabular}

Key as in table 3.
SECOND DEGREE RELATIVES

This series provides the first information on grandchildren of probands. The proportion affected of grandchildren, nephews and nieces, and uncles and aunts is shown in table 5 and the malformation, so far as is known, is shown in the appendix. It will be seen that only two of 251 grandchildren were affected, $0.47 \%( \pm 0.18)$ of nephews and nieces, and $0.59 \%( \pm 0 \cdot 13)$ of uncles and aunts. In addition none of 60 half-sibs ( 30 paternal and 30 maternal) was affected.

\section{THIRD DEGREE RELATIVES}

The proportion affected of cousins is shown in table 6: it was $0.27 \%( \pm 0.08)$. Dividing into paternal and maternal cousins, the proportions affected are $0.20 \%( \pm 0.10)$ and $0.33 \%( \pm 0 \cdot 11)$, respectively. Subdividing further gives: fathers' brothers' children $0.19 \%( \pm 0.13)$; fathers' sisters' children $0.20 \%$ $( \pm 0.14) ;$ mothers' brothers' children $0.57 \%$ $( \pm 0.21)$, and mothers' sisters' children $0.14 \%$ $( \pm 0 \cdot 10)$.

\section{CONSANGUINITY}

Among the marriages of the parents of the probands there were two first cousin (of 149, 304) and one second cousin (of 137) marriages. The figure for the general population at that time is not precisely known but is probably only about two first cousin marriages per thousand.

CLEFT PALATE ALONE IN RELATIVES

The proportion of relatives documented as having 
TABLE 5 Second degree relatives (excluding half sibs) of probands: numbers affected shown in brackets

\begin{tabular}{|c|c|c|c|c|c|c|c|c|c|}
\hline \multirow[b]{3}{*}{ Probands } & \multicolumn{5}{|c|}{ Grandchildren } & \multicolumn{4}{|c|}{ Nephews and nieces } \\
\hline & \multicolumn{2}{|l|}{ Sons } & \multicolumn{2}{|c|}{ Daughters } & \multirow{2}{*}{$\begin{array}{l}\text { All } \\
\text { grandchildren }\end{array}$} & \multicolumn{2}{|c|}{ Brothers } & \multicolumn{2}{|l|}{ Sisters } \\
\hline & Sons & Daughters & $\overline{\text { Sons }}$ & Daughters & & en Sons & Daughters & Sons & Daughters \\
\hline \multirow[t]{2}{*}{$\begin{array}{l}\text { Male } \\
\text { CLu } \\
\text { CLb } \\
\text { CLCPu } \\
\text { CLCPb }\end{array}$} & $\begin{array}{r}4 \\
2 \\
18 \\
8\end{array}$ & $\begin{array}{r}2 \\
0 \\
14 \\
4\end{array}$ & $\begin{array}{c}12 \\
0 \\
31(2) \\
8\end{array}$ & $\begin{array}{r}20 \\
0 \\
37 \\
5\end{array}$ & $\begin{array}{c}38 \\
2 \\
100(2) \\
25\end{array}$ & $\begin{array}{c}75(1) \\
1 \\
103 \\
40(1)\end{array}$ & $\begin{array}{c}71 \\
6 \\
118(1) \\
39\end{array}$ & $\begin{array}{c}122(1) \\
2 \\
134(1) \\
50\end{array}$ & $\begin{array}{c}99 \\
3 \\
139(1) \\
48 \\
\end{array}$ \\
\hline & 32 & 20 & $51(2)$ & 62 & $165(2)$ & $219(2)$ & $234(1)$ & $308(2)$ & $289(1)$ \\
\hline \multirow[t]{4}{*}{$\begin{array}{l}\text { Female } \\
\text { CLu } \\
\text { CLb } \\
\text { CLCPu } \\
\text { CLCPb }\end{array}$} & $\begin{array}{l}5 \\
0 \\
8 \\
6\end{array}$ & $\begin{array}{r}6 \\
0 \\
10 \\
5\end{array}$ & $\begin{array}{r}11 \\
2 \\
6 \\
5\end{array}$ & $\begin{array}{r}12 \\
0 \\
9 \\
1\end{array}$ & $\begin{array}{r}34 \\
2 \\
33 \\
17\end{array}$ & $\begin{array}{r}30 \\
4 \\
29 \\
14\end{array}$ & $\begin{array}{l}34 \\
6 \\
36 \\
16(1)\end{array}$ & $\begin{array}{r}47 \\
2 \\
63 \\
33\end{array}$ & $\begin{array}{r}45 \\
5 \\
52 \\
22\end{array}$ \\
\hline & 19 & 21 & 24 & 22 & $\begin{array}{l}86 \\
251(2) \\
0 \cdot 80 \%\end{array}$ & 77 & 92(1) & 145 & 124 \\
\hline & & & \multicolumn{4}{|c|}{ Uncles and aunts } & & \multirow{2}{*}{\multicolumn{2}{|c|}{$\begin{array}{l}\text { Total second } \\
\text { degree relatives }\end{array}$}} \\
\hline & \multicolumn{2}{|c|}{ All nephews and nieces } & $\begin{array}{l}\text { Fathers } \\
\text { Brothers }\end{array}$ & Sisters & $\begin{array}{l}\text { Mothers } \\
\text { Brothers }\end{array}$ & Sisters & All uncles and au & & \\
\hline \multirow[t]{2}{*}{$\begin{array}{l}\text { Male } \\
\text { CLu } \\
\text { CLb } \\
\text { CLCPu } \\
\text { CLCPb }\end{array}$} & $\begin{array}{c}367(2) \\
12 \\
494(3) \\
177(1)\end{array}$ & & $\begin{array}{c}160 \\
5 \\
282(1) \\
73(2)\end{array}$ & $\begin{array}{r}148(2) \\
8(1) \\
281(2) \\
80(2)\end{array}$ & $\begin{array}{c}166 \\
1 \\
325(2) \\
94(2)\end{array}$ & $\begin{array}{l}192 \\
5 \\
314(1) \\
101\end{array}$ & $\begin{array}{r}666(2) \\
19(1) \\
1202(6) \\
348(6)\end{array}$ & $\begin{array}{r}10 \\
17 \\
5\end{array}$ & \\
\hline & $1050(6)$ & & $520(3)$ & $517(7)$ & $586(4)$ & $612(1)$ & $2235(15)$ & & 23) \\
\hline \multirow[t]{2}{*}{$\begin{array}{l}\text { Female } \\
\text { CLu } \\
\text { CLb } \\
\text { CLCPu } \\
\text { CLCPb }\end{array}$} & $\begin{array}{c}156 \\
17 \\
180 \\
85(1)\end{array}$ & & $\begin{array}{c}127(1) \\
13 \\
91 \\
52\end{array}$ & $\begin{array}{l}111 \\
14 \\
91 \\
47(1)\end{array}$ & $\begin{array}{r}109 \\
18 \\
100 \\
75\end{array}$ & $\begin{array}{c}130(2) \\
21 \\
103(1) \\
63\end{array}$ & $\begin{array}{c}477(3) \\
66 \\
385(1) \\
237(1)\end{array}$ & & \\
\hline & $\begin{array}{c}438(1) \\
\\
1488(7) \\
0.47 \%\end{array}$ & & $283(1)$ & 263(1) & 302 & $317(3)$ & $\begin{array}{l}1165(5) \\
3400(20) \\
0.59 \%\end{array}$ & $\begin{array}{l}168 \\
51\end{array}$ & $\begin{array}{l}\text { 5) } \\
36 \% \\
56 \% \\
5\end{array}$ \\
\hline
\end{tabular}

Key as in table 3.

TABLE 6 Third degree relatives of probands: numbers affected shown in brackets

\begin{tabular}{|c|c|c|c|c|c|c|c|c|c|c|c|}
\hline \multirow[b]{3}{*}{ Probands } & \multicolumn{4}{|l|}{ Fathers } & \multirow{3}{*}{$\begin{array}{l}\text { All paternal } \\
\text { cousins }\end{array}$} & \multicolumn{4}{|l|}{ Mothers } & \multirow{3}{*}{\multicolumn{2}{|c|}{$\begin{array}{l}\text { All maternal Total all } \\
\text { cousins } \quad \text { cousins }\end{array}$}} \\
\hline & \multicolumn{2}{|c|}{ Brothers } & \multicolumn{2}{|l|}{ Sisters } & & \multicolumn{2}{|l|}{ Brothers } & \multicolumn{2}{|l|}{ Sisters } & & \\
\hline & Sons & Daughters & Sons & Daughters & & $\overline{\text { Sons }}$ & Daughters & $\overline{\text { Sons }}$ & Daughters & & \\
\hline \multicolumn{12}{|l|}{ Male } \\
\hline CLu & 103(1) & 94 & 88 & 100 & $385(1)$ & $134(1)$ & 104 & 137 & 166 & $541(1)$ & $926(2)$ \\
\hline CLb & 10 & 2 & 4 & 2 & 18 & 0 & 1 & 5 & 5 & 11 & $29^{\circ}$ \\
\hline CLCPu & 203 & 193 & $165(1)$ & 182 & $743(1)$ & $245(4)$ & 245 & $240(1)$ & 247 & $977(5)$ & $1720(6)$ \\
\hline $\mathrm{CLCPb}$ & 46 & 53 & $45(1)$ & 54 & 198(1) & $69(1)$ & 55 & 58 & 59 & 241(1) & 439(2) \\
\hline Total & $362(1)$ & 342 & $302(2)$ & 338 & $1344(3)$ & $448(6)$ & 405 & $440(1)$ & 477 & $1770(7)$ & $\begin{array}{l}3114(10) \\
0.32 \%\end{array}$ \\
\hline \multicolumn{12}{|l|}{ Female } \\
\hline $\mathrm{CLu}$ & 81 & 70 & 85 & 99 & 335 & 76 & $83(1)$ & 107 & $114(1)$ & $380(2)$ & $715(2)$ \\
\hline CLb & 4 & 5 & 6 & 5 & 20 & 9 & 7 & 20 & 29 & 65 & 85 \\
\hline CLCPu & $59(1)$ & 59 & 55 & 51 & $224(1)$ & 81 & 67 & 88 & 96 & 332 & $556(1)$ \\
\hline CLCPb & 48 & 22 & 27 & 18 & 115 & 28 & 32 & 49 & 50 & 159 & 274 \\
\hline Total & $192(1)$ & 156 & 173 & 173 & $694(1)$ & 194 & $189(1)$ & 264 & $289(1)$ & $936(2)$ & $\begin{array}{l}1630(3) \\
0.18 \%\end{array}$ \\
\hline Total & \multicolumn{2}{|c|}{$\begin{array}{l}1052(2) \\
0.19 \%\end{array}$} & \multicolumn{2}{|c|}{$\begin{array}{l}986(2) \\
0.20 \%\end{array}$} & $\begin{array}{c}2038(4) \\
0 \cdot 20 \%\end{array}$ & \multicolumn{2}{|c|}{$\begin{array}{c}1236(7) \\
0.57 \%\end{array}$} & \multicolumn{2}{|c|}{$\begin{array}{l}1470(2) \\
0.14 \%\end{array}$} & $\begin{array}{l}2706(9) \\
0.33 \%\end{array}$ & $\begin{array}{r}4744(13) \\
0.27 \%\end{array}$ \\
\hline
\end{tabular}

Key as in table 3. 
cleft palate alone was one brother (of 230), no sisters, no grandchildren, one nephew (of 406), no nieces, no uncles, one aunt (of 99), and three first cousins (of $279,326)$. In addition, one uncle (of 39) and one cousin (of 55) were said by a relative who knew them well to have cleft palate alone. This is no more than would be expected by chance in a sample of nearly 12000 relatives.

\section{Discussion}

In both methods (involving personal visits to the homes of probands) and findings this series was closest to the early Danish series. ${ }^{1}$ In the present study there was a more complete exclusion of syndromes (for example, the Danish series included two patients where a parent had lower lip fistulae, one patient with cleft hands, and two with Down's syndrome). This series, for the family study, also included a lower proportion of patients with the more severe degrees of malformation, the proportion of unilateral CL, bilateral CL, unilateral CLCP, and bilateral CLCP cases being 35.8, 2.6, 44.6, and $17.0 \%$ compared with $24 \cdot 3,3 \cdot 4,51 \cdot 2$, and $21 \cdot 1 \%$ in the Danish series. The latter distribution is typical for series of infants coming to operation. This series goes beyond the first Danish series in that it includes many children and some grandchildren. As in Denmark the birth frequency of the malformation in the general population is about $0 \cdot 1 \%$.

The twins in this series add little to the previous data, ${ }^{14} 15$ which suggest a pair-wise concordance of 30 to $40 \%$. Our series like others, with the exception of the Tasmanian series of Rank and Thomson, ${ }^{16}$ gives no indication of any increase in $\mathrm{CP}$ alone in relatives of CLCP probands.

This series makes it clear that the proportion affected of children is close to the proportion affected of the sibs of the same probands, $3 \cdot 2( \pm 0 \cdot 6)$ compared to $2 \cdot 8( \pm 0 \cdot 5) \%$. This similarity confirms the findings in smaller series, eight in $171(4.7 \pm$ $1.7 \%$ ) in $\mathrm{Utah}^{7}$ (sib proportion $4.6 \pm 0.6 \%$ for the whole series of probands) and 18 in $513(3.5 \pm 0 \cdot 8 \%)$ in the follow-up of the original Danish series (sib proportion for the same probands $3.9+0.6 \%$ ). There is then no indication of any substantial recessive element in the inheritance of the condition, nor of any persistent direct maternal non-genetic influence. The lower proportion affected of parents of probands in this and other series is not an indication of recessive inheritance, nor a dominance component in the liability on the multifactorial threshold model, but rather of the lowered reproductive fitness of patients born two generations ago.

This series also confirms an effect of severity of the malformation in the proband on the proportion affected of sibs and children. Excluding the few cases of bilateral CL (which are difficult to classify for severity) and extracting the same information (excluding stillbirths and co-twins) from the details given in the report of the original Copenhagen series, ${ }^{1}$ the effect of severity is shown in table 7. Data are also shown in table 7 for the second Danish and the Utah and Arizona series (in which bilateral CL is classed with unilateral $C L$ ), and for sibs in the Hungarian series and children in the Danish followup, for which the comparison is only between CL and CLCP. While no individual series shows significant differences by severity, their general consistency leaves little doubt of such an effect. The second Copenhagen series ${ }^{12}$ gives a somewhat higher proportion of sibs affected in each class than other series, and this may reflect some bias from a readier response to a questionnaire, to which only some $70 \%$ replied, from families with more than one member affected. But this bias is likely to have applied consistently to each degree of severity.

Our series also shows a small effect of sex of proband on the proportion of sibs plus children affected, $2 \cdot 7( \pm 0.5)$ and $3 \cdot 4( \pm 0 \cdot 7) \%$ for male and female probands, respectively. A comparison with the other large series where this information is available is shown in table 8 .

It will be seen that while the original Danish

TABLE 7 Proportion affected ( $\%$ ) of first degree relatives by severity of malformation

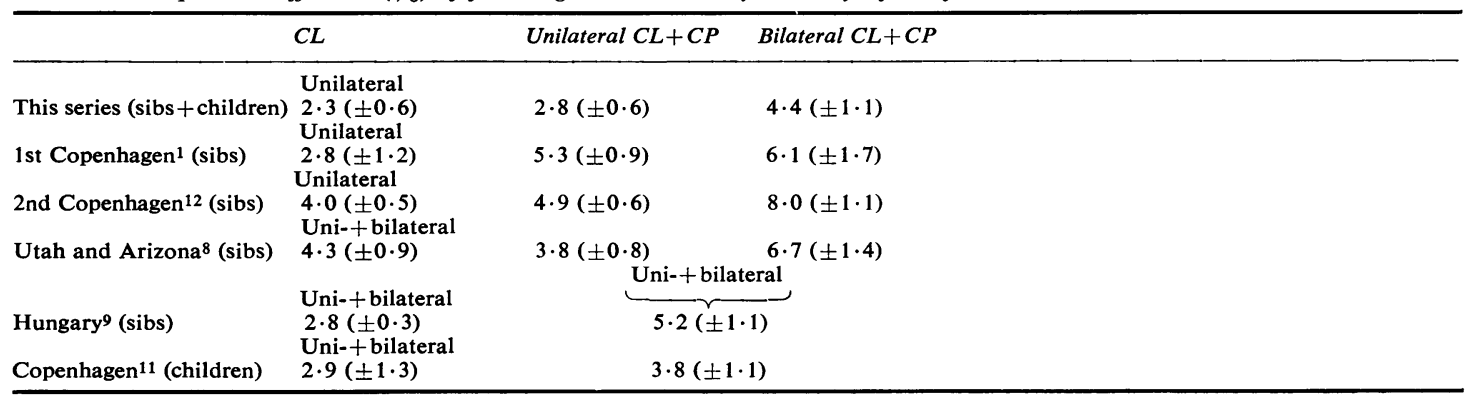


TABLE 8 Proportion affected (\%) of first degree relatives by sex of proband

\begin{tabular}{|c|c|c|}
\hline & Male probands & Female probands \\
\hline $\begin{array}{l}\text { This series (sibs and children) } \\
\text { 1st Copenhagen }{ }^{1} \text { (sibs) } \\
\text { Copenhagen }{ }^{11} \text { (children) } \\
\text { 2nd Copenhagen }{ }^{12} \text { (sibs) } \\
\text { Utah and Arizona }{ }^{8} \text { (sibs) }\end{array}$ & $\begin{array}{l}2 \cdot 7( \pm 0 \cdot 5) \\
5 \cdot 0( \pm 0 \cdot 8) \\
3 \cdot 8( \pm 1 \cdot 1) \\
4 \cdot 9( \pm 0 \cdot 4) \\
3 \cdot 6( \pm 0 \cdot 6)\end{array}$ & $\begin{array}{l}3 \cdot 4( \pm 0 \cdot 7) \\
4 \cdot 9( \pm 1 \cdot 1) \\
3 \cdot 2( \pm 1 \cdot 0) \\
5 \cdot 6( \pm 0 \cdot 7) \\
4 \cdot 7( \pm 0 \cdot 9)\end{array}$ \\
\hline
\end{tabular}

series shows no difference in sibs, nor in children, in the follow-up survey, the other three series do show a difference, though none individually is significant. The differences are of the order expected on the multifactorial threshold model for a condition where the sex ratio is about 2 . In Japan, where the sex ratio is closer to one, understandably no effect of sex is seen. ${ }^{13}$ The probands are not distinguished by sex in the Hungarian series.

It is also of interest and important for genetic counselling to know if the presence of an affected first degree relative increases the proband's risk of having affected children or sibs.

Risks to sibs where one parent is affected: in ten such families in our series one in 14 sibs was affected. In the original Danish series ${ }^{1}$ it may be seen that eight in 55 sibs were affected, and in the Utah and Arizona series, ${ }^{8}$ seven in 45 . There is a clear indication of an increased risk, and that it is about $14 \%$.

Risks to further sibs where the proband already has one affected sib: in our series four such probands $(73,189,259$, and 408$)$ had nine later born sibs of whom none was affected. However, proband 309 was reported, without documentary confirmation, to have had older twin-born sisters, both affected and dying in infancy, and a younger sister affected. In addition, where a proband had a younger sib affected $(147,253,263,293,300,341)$, two of 18 sibs born after the second affected child were also affected. In the original Danish series in the same two situations, four in 28 and one in 16 sibs were affected, and in the Utah and Arizona series, combining the two situations, seven in $\mathbf{4 8}$ sibs were affected. Again there is an indication of a raised risk, perhaps to about $10 \%$.

Risks to sibs where an uncle or aunt, a first cousin, but no closer relative (other than a child or nephew or niece, who would normally not have been born when the parent of the proband was asking for genetic counselling) is affected: in our series the proportions affected were one in 37 and one in 25 , respectively. There is then no indication of any increased risk. The first Danish series indicates no increased risk to sibs in these situations, and in the report of the Canadian series it is stated that there is no increased risk to sibs where there was 'a family history', but not a parent affected. In the Utah and
Arizona series there was a small increased risk to sibs where a second or third degree relative was affected.

Risks to children of probands where the proband has an affected sib or parent: in our series only one in 53 and one in 24 children, respectively, were affected. Perhaps surprisingly, there is no indication in the few informative families of any raised risk over that for all children of probands. The other series give no information on this risk.

Risks to children of probands where an aunt or uncle, a nephew or niece, but not a parent or sib, is affected: in our series in these two situations one in 24 and 0 in ten were affected. Again where the proband had an affected cousin, but not a closer relative, 0 in 28 children were affected. There is thus no indication of any increased risk in these situations. The other series give no information on these risks.

The most economical hypothesis to explain the family findings in this and the other surveys is the multifactorial threshold model-that the liability to develop the condition is determined by genetic predisposition because of variation at, at least, several gene loci and influenced by sex, interacting with intrauterine environmental factors. The hypothesis that a single mutant gene makes a major contribution to the total liability is possible, but improbable. It would require an unusually high mutation rate to this gene to maintain the malformation at a birth frequency of one in 1000 live births in the face of past reduced fertility of those affected. It would also tend to give a higher proportion affected of second or third degree relatives compared to that of first degree relatives than is observed in the family studies, since half the first degree, a quarter of the second degree, and an eighth of the third degree relatives would be expected to share the major gene with the proband. The proportions affected of such relatives observed in the series, $3 \cdot 0,0 \cdot 56$, and 0.27 in first, second, and third degree relatives, respectively, is, however, close to that which would be expected from the multifactorial model, with a covariance for the liability of about $80 \%$ of that expected with simple additive inheritance and a birth frequency in the population of $0.1 \%$. It could be argued that the greater reduction in the proportion affected in second and third, compared to first, degree relatives than would be expected if a single mutant gene made a major contribution, could be the result of a progressive dilution of the common environment. But the apparent similarity of the proportion affected in different types of second degree relatives is more easily understood as resulting from the similar proportion of shared genes than from a similar degree of environment shared by the proband and his uncles and aunts, nephews and nieces, and grandchildren. 
APPENDIX Key: ${ }^{*}=$ traced but no children; $D, N I$ or $S=$ traced direct, National Insurance or Southport; $C=$ traced by child; $Y=$ child too young to have had a child; $F=$ not traced, emigrated or dead; $-=$ no attempt to trace; $L=$ affected $C L ; P=$ affected $C P ; L P=$ affected $C L+C P ; u=$ unilateral; $b=$ bilateral; $P r=$ proband

\begin{tabular}{|c|c|c|c|c|c|c|c|c|c|c|c|c|c|c|c|c|c|c|c|}
\hline \multirow[b]{2}{*}{$\begin{array}{l}\text { Serial } \\
\text { No }\end{array}$} & \multirow{2}{*}{$\begin{array}{l}\text { Month } \\
\text { and } \\
\text { year of } \\
\text { birth }\end{array}$} & \multirow{2}{*}{\multicolumn{3}{|c|}{$\begin{array}{l}\text { Method } \\
\text { traced in } \\
1958 / 73 / 78\end{array}$}} & \multicolumn{2}{|c|}{ Children } & \multicolumn{4}{|c|}{ Sibs (excluding twins) } & \multicolumn{4}{|c|}{ Grandchildren } & Nephen & ws and & $d$ nieces & & \\
\hline & & & & & Sons & Daus & $\begin{array}{l}\text { Before } \\
\text { Bros }\end{array}$ & esis & $\begin{array}{l}\text { After } \\
\text { Bros }\end{array}$ & Sis & $\begin{array}{l}\text { Sons } \\
\text { Sons }\end{array}$ & Daus & $\begin{array}{l}\text { Daugh } \\
\text { Sons }\end{array}$ & $\begin{array}{l}\text { hters } \\
\text { Daus }\end{array}$ & $\begin{array}{l}\text { Brothe } \\
\text { Sons }\end{array}$ & $\begin{array}{l}\text { ers } \\
\text { Daus }\end{array}$ & $\begin{array}{l}\text { Sisters } \\
\text { Sons }\end{array}$ & ${ }^{s}$ Daus & $\begin{array}{l}\text { relatives } \\
\text { and spouses }\end{array}$ \\
\hline $\begin{array}{l}\text { MALE } \\
\text { GROUF }\end{array}$ & I: CLu & & & & & & & & & & & & & & & & & & \\
\hline 1 & 1.19 & D & $\mathbf{F}$ & $\mathbf{s}$ & 1 & 1 & 6 & 2 & 0 & 0 & 0 & 0 & 0 & 0 & 7 & 8 & 4 & 2 & \\
\hline 2 & 7.19 & NI & D & $\tilde{\mathbf{S}}$ & 2 & 0 & 0 & 1 & 1 & 0 & 0 & 0 & 0 & 0 & i & 1 & i & 2 & \\
\hline 3 & 4.20 & D & $\overline{\mathbf{F}}$ & $\mathbf{S}$ & 0 & 2 & 1 & 2 & 0 & 0 & 0 & 0 & 1 & 1 & 0 & o & 0 & 0 & \\
\hline 4 & 4.20 & $\overrightarrow{\mathbf{D}}$ & $\mathbf{F}$ & $\tilde{\mathbf{S}}$ & 1 & 0 & 3 & 2 & 0 & 0 & 0 & 0 & 0 & 0 & 3 & 0 & 1 & 1 & \\
\hline 5 & 4.20 & NI & $\mathbf{F}$ & $\mathbf{F}$ & 1 & 1 & o & 0 & 0 & 2 & 0 & 0 & $\mathbf{0}$ & 0 & $\mathbf{0}$ & $\mathbf{0}$ & 2 & 0 & \\
\hline 6 & 5.20 & NI & D & D & 1 & 1 & 1 & 1 & 0 & 1 & 0 & $\mathbf{0}$ & 0 & 0 & 0 & $\mathbf{0}$ & 3 & 1 & \\
\hline 7 & 6.20 & NI & $\mathbf{F}$ & $\overline{\mathbf{F}}$ & 1 & 0 & 0 & 1 & 1 & 0 & 0 & $\mathbf{0}$ & 0 & 0 & $\mathbf{0}$ & 0 & 0 & 1 & \\
\hline 8 & 7.20 & NI & $\mathbf{F}$ & $\mathbf{S}$ & 3 & 0 & 0 & 0 & 0 & 2 & 1 & 2 & 0 & 0 & o & 0 & 0 & 0 & \\
\hline 9 & 7.21 & D & $\mathbf{F}$ & $\mathbf{F}$ & 0 & 1 & 0 & 0 & 0 & 0 & 0 & 0 & 0 & 0 & 0 & 0 & 0 & $\mathbf{0}$ & \\
\hline 10 & 10.21 & NI & D & D & $\mathbf{0}$ & i & 1 & 1 & $\mathbf{0}$ & 1 & 0 & $\mathbf{0}$ & 0 & 0 & 1 & 0 & 1 & 0 & \\
\hline 11 & 2.23 & D & $\mathbf{F}$ & $\mathbf{S}$ & 1 & 0 & 2 & 4 & $\mathbf{0}$ & i & $\mathbf{0}$ & $\mathbf{0}$ & 0 & $\mathbf{0}$ & 5 & 1 & 6 & 11 & \\
\hline 12 & 2.23 & NI & $\mathbf{F}$ & D & o & 2 & 2 & 0 & 0 & $\mathbf{0}$ & 0 & 0 & 3 & 0 & 2 & 3 & 0 & 0 & Twin $\operatorname{Pr} 122$ \\
\hline 13 & 5.23 & NI & $\mathbf{F}$ & $\mathbf{S}$ & $\mathbf{0}$ & 2 & 0 & 0 & $\mathbf{0}$ & 0 & 0 & 0 & 1 & 2 & 0 & 0 & 0 & 0 & \\
\hline 14 & 7.23 & NI & D & D & 1 & 1 & 0 & 0 & 1 & 2 & 0 & 0 & $i$ & 1 & 0 & 0 & 2 & 1 & \\
\hline 15 & 3.24 & NI & D & D & 1 & i & 1 & 0 & 0 & 1 & 0 & 0 & 0 & 0 & 0 & 0 & 0 & 0 & \\
\hline 16 & 12.24 & NI & D & D & & 5 & 0 & 2 & 1 & 1 & 1 & 0 & 3 & 4 & 2 & 1 & 5 & 4 & \\
\hline 17 & 1.25 & NI & $\mathbf{F}$ & $\mathbf{S}$ & 0 & 1 & 1 & 0 & 1 & 0 & 0 & 0 & 0 & 2 & 0 & 1 & 0 & 0 & \\
\hline 18 & 6.25 & D & $\mathbf{F}$ & $\mathbf{F}$ & 1 & 0 & 0 & 0 & 0 & 0 & 0 & 0 & 0 & 0 & 0 & 0 & $\mathbf{0}$ & $\mathbf{0}$ & \\
\hline 19 & 7.25 & NI & $\mathbf{F}$ & $\mathbf{S}$ & $1 \mathrm{LPu}$ & 0 & 0 & 0 & 4 & 0 & 0 & 0 & 0 & 0 & 1 & 0 & o & 0 & \\
\hline 20 & 8.25 & $\mathrm{NI}^{*}$ & - & D & 0 & 2 & 2 & 1 & 0 & 0 & 0 & 0 & 0 & 0 & 0 & 0 & 0 & 0 & \\
\hline 21 & 8.25 & NI & $\mathbf{F}$ & $\mathbf{F}$ & 2 & 0 & 0 & 0 & 0 & 0 & 0 & 0 & 0 & 0 & 0 & 0 & 0 & 0 & \\
\hline 22 & 4.26 & NI & D & D & 0 & 1 & 0 & 0 & 0 & 2 & 0 & 0 & 0 & 0 & 0 & 0 & 0 & 1 & \\
\hline 23 & 5.27 & D & $\mathbf{F}$ & $\mathbf{F}$ & 3 & 0 & $\mathbf{0}$ & 1 & 0 & 0 & 0 & 0 & 0 & 0 & 0 & 0 & 0 & 0 & \\
\hline 24 & 5.27 & NI & D & D & 1 & 0 & 0 & 0 & 0 & o & 0 & 0 & 0 & 0 & 0 & 0 & 0 & 0 & \\
\hline 25 & 5.27 & D & $\mathbf{F}$ & $\mathbf{F}$ & 2 & 1 & 0 & 0 & 2 & 0 & 0 & 0 & 0 & 0 & 2 & 0 & 0 & 0 & \\
\hline 26 & 7.27 & NI & D & D & 3 & 1 & 2 & 2 & 0 & 0 & 0 & 0 & 0 & 0 & 0 & 3 & 6 & 0 & \\
\hline 27 & 8.27 & D & $\mathbf{F}$ & $\mathbf{S}$ & 0 & 1 & 2 & 2 & 1 & 8 & 0 & 0 & 0 & 2 & 1 & 3 & $\left\{\begin{array}{l}1 \mathrm{LPu} \\
6\end{array}\right.$ & 8 & \\
\hline 28 & 1.28 & NI & D & D & 0 & 2 & 1 & 0 & 1 & 0 & 0 & 0 & 0 & 0 & 1 & 3 & 0 & 0 & Mo Lu \\
\hline 29 & 6.28 & NI & D & $\mathbf{S}$ & 2 & 3 & 2 & 3 & 1 & 0 & 0 & 0 & 0 & 0 & 4 & 1 & 2 & 3 & \\
\hline 30 & 1.29 & NI & D & D & 0 & 3 & 0 & 0 & 4 & 4 & 0 & 0 & 0 & 3 & 5 & 1 & 0 & 1 & \\
\hline 31 & 2.29 & NI & D & D & 1 & 0 & 0 & 0 & 0 & 0 & 0 & 0 & 0 & 0 & 0 & 0 & 0 & 0 & \\
\hline 32 & 6.29 & NI & $\mathbf{F}$ & $\mathbf{F}$ & 0 & 1 & 0 & 0 & 1 & 2 & 0 & 0 & 0 & 0 & 1 & 0 & 1 & 1 & Fa Si Lu \\
\hline 33 & 7.29 & NI & D & D & 2 & 3 & 1 & 0 & 0 & 0 & 2 & 0 & 1 & 1 & 0 & 1 & 0 & 0 & Fa Bro Son L \\
\hline 34 & 8.29 & $\mathrm{D}^{*}$ & - & $\mathbf{S}$ & 1 & 1 & 0 & 0 & 0 & 2 & 0 & 0 & 0 & 0 & 0 & 0 & 4 & 1 & \\
\hline 35 & 10.29 & NI & D & D & 1 & i & $\mathbf{0}$ & 0 & 3 & 0 & 0 & 0 & $\mathbf{0}$ & 0 & 0 & 1 & 0 & 0 & \\
\hline 36 & 10.29 & $\mathrm{D}^{*}$ & - & $\mathbf{S}$ & $i$ & 1 & 0 & 1 & 0 & $\mathbf{0}$ & 0 & 0 & 0 & 0 & 0 & 0 & 1 & 1 & \\
\hline 37 & 12.29 & NI & $\mathbf{F}$ & $\mathbf{S}$ & 3 & 1 & 2 & 1 & 2 & 2 & 0 & 0 & 0 & $\mathbf{0}$ & $\left\{\begin{array}{l}11 \\
1\end{array}\right.$ & 1 & 3 & 4 & \\
\hline 38 & 1.30 & NI & $\mathbf{F}$ & $\mathbf{s}$ & 0 & 3 & 1 & 2 & 2 & 2 & $\mathbf{0}$ & 0 & 1 & o & 0 & $\mathbf{0}$ & 2 & 2 & \\
\hline 39 & 1.30 & NI & $\mathbf{F}$ & $\mathbf{F}$ & 1 & 0 & 3 & 2 & 2 & 2 & $\mathbf{0}$ & 0 & 0 & 0 & 0 & 5 & 7 & 7 & \\
\hline 40 & 2.30 & NI & $\mathbf{F}$ & $\mathbf{S}$ & 2 & 3 & 0 & 0 & 1 & 0 & 0 & 0 & 0 & 1 & 0 & 0 & 0 & 0 & \\
\hline 41 & 4.30 & NI & D & D & 2 & 1 & 6 & 1 & 1 & 1 & 0 & 0 & 0 & 0 & 7 & 6 & 1 & 2 & \\
\hline 42 & 4.30 & $\mathrm{NI}^{*}$ & - & $\mathbf{S}$ & 2 & 0 & 0 & 0 & 0 & 0 & 0 & 0 & 0 & 0 & 0 & 0 & 0 & 0 & \\
\hline 43 & 6.30 & NI & $\mathbf{F}$ & $\mathbf{S}$ & 0 & 4 & 2 & 4 & 0 & 0 & 0 & 0 & 0 & $\mathbf{0}$ & 1 & 1 & 5 & 2 & \\
\hline 44 & 7.30 & NI & $\mathbf{F}$ & $\mathbf{S}$ & $1 \mathrm{Lu}$ & 2 & 0 & 0 & 0 & 1 & 0 & 0 & 0 & 0 & 0 & 0 & 0 & 0 & $\mathrm{Fa} \mathrm{Fa} \mathrm{Fa} \mathrm{L}$ \\
\hline 45 & 8.30 & $\mathbf{D}^{*}$ & - & D & 2 & 0 & 1 & 1 & 1 & 2 & 0 & 0 & 0 & 0 & 0 & 1 & 2 & 1 & \\
\hline 46 & 12.30 & NI & $\mathbf{F}$ & $\mathbf{S}$ & 1 & 1 & 3 & 1 & 3 & 0 & 0 & 0 & 0 & 0 & 5 & 2 & 0 & 0 & \\
\hline 47 & 2.31 & NI & D & $\mathbf{S}$ & 0 & 2 & 0 & 0 & 0 & 0 & 0 & 0 & 0 & 0 & 0 & 0 & o & 0 & \\
\hline 48 & 4.31 & D & D & $\mathbf{S}$ & 1 & 3 & 0 & 1 & 1 & 0 & 0 & 0 & 0 & 1 & 0 & 0 & 0 & 0 & \\
\hline 49 & 4.31 & NI & $\mathbf{F}$ & D & 0 & 2 & 0 & 1 & $i$ & 1 & 0 & 0 & 0 & 0 & 0 & 0 & 2 & 2 & \\
\hline 50 & 7.31 & NI & $\mathbf{F}$ & $\mathbf{S}$ & 2 & 1 & 1 & 0 & 0 & 0 & o & 0 & 0 & 0 & 0 & 1 & 0 & 0 & \\
\hline 51 & 7.31 & D & D & $\mathbf{F}$ & 1 & 2 & 1 & 1 & 0 & 0 & 0 & 0 & 0 & 0 & 0 & 0 & 0 & 0 & \\
\hline 52 & 8.31 & $\mathbf{D}^{*}$ & - & D & 0 & 3 & 0 & 0 & 0 & 1 & 0 & 0 & 0 & 0 & 0 & 0 & 1 & 1 & \\
\hline 53 & 8.31 & $\mathrm{NI}^{*}$ & - & D & 2 & 0 & 0 & 0 & 3 & 1 & 0 & 0 & 0 & 0 & 3 & 6 & 0 & 1 & \\
\hline 54 & 12.31 & D & $\mathbf{F}$ & $\mathbf{S}$ & 1 & 1 & 4 & 4 & 0 & 3 & 0 & 0 & 0 & 0 & 3 & 5 & 11 & 6 & \\
\hline 55 & 12.31 & $\mathrm{NI}^{*}$ & - & $\mathbf{S}$ & 1 & 0 & 1 & 4 & 0 & 1 & 0 & 0 & 0 & 0 & 0 & 0 & 11 & 6 & Mo Si Dau P \\
\hline 56 & 3.32 & D & D & D & 2 & 2 & 1 & 2 & 0 & 0 & 0 & $\mathbf{0}$ & 1 & 2 & $\mathbf{0}$ & $\mathbf{0}$ & 2 & 3 & \\
\hline 57 & 7.32 & $\mathrm{D}^{*}$ & - & $\mathbf{S}$ & 1 & 1 & 1 & 0 & 1 & 1 & 0 & 0 & 0 & 0 & 2 & 1 & $\mathbf{0}$ & o & \\
\hline 58 & 8.32 & $\mathbf{D}^{*}$ & - & $\mathbf{S}$ & 4 & 0 & 2 & 0 & 0 & 1 & 0 & 0 & 0 & 0 & 2 & 1 & 0 & o & \\
\hline 59 & 9.32 & $\mathrm{D}^{*}$ & - & $\mathbf{S}$ & 1 & 2 & 0 & 0 & 0 & 0 & 0 & 0 & 0 & 0 & 0 & 0 & 0 & 0 & \\
\hline 60 & 2.33 & $\mathrm{NI}^{*}$ & - & D & 1 & 1 & 0 & 0 & 0 & 0 & 0 & 0 & 0 & $\mathbf{0}$ & 1 & 2 & 0 & 0 & \\
\hline 61 & 5.33 & $\mathrm{D}^{*}$ & - & D & 1 & 4 & 1 & 2 & 1 & 0 & 0 & 0 & 0 & 0 & 4 & 0 & 4 & 4 & \\
\hline 62 & 6.33 & NI & D & D & 1 & i & 1 & 0 & 0 & 0 & 0 & 0 & $\mathbf{0}$ & 0 & 0 & 0 & 0 & 0 & \\
\hline 63 & 1.34 & D & $\mathbf{F}$ & D & 1 & 1 & 0 & 0 & 2 & o & o & 0 & $\mathbf{0}$ & 0 & 0 & 0 & 0 & 0 & \\
\hline 64 & 4.34 & D & D & $\mathbf{S}$ & 1 & 1 & 0 & 4 & 2 & 0 & 0 & o & $\mathbf{0}$ & 0 & 0 & 0 & 5 & 1 & \\
\hline
\end{tabular}


APPENDIX - continued

\begin{tabular}{|c|c|c|c|c|c|c|c|c|c|c|c|c|c|c|c|c|c|c|c|}
\hline \multirow{3}{*}{$\begin{array}{l}\text { Serial } \\
\text { No }\end{array}$} & \multirow{3}{*}{$\begin{array}{l}\text { Month } \\
\text { and } \\
\text { year of } \\
\text { birth }\end{array}$} & \multirow{3}{*}{\multicolumn{3}{|c|}{$\begin{array}{l}\text { Method } \\
\text { traced in } \\
1958 / 73 / 78\end{array}$}} & \multicolumn{2}{|c|}{ Children } & \multicolumn{4}{|c|}{ Sibs (excluding twins) } & \multicolumn{4}{|c|}{ Grandchildren } & \multicolumn{4}{|c|}{ Nephews and nieces } & \multirow{3}{*}{$\begin{array}{l}\text { Other affected } \\
\text { relatives } \\
\text { and spouses }\end{array}$} \\
\hline & & & & & \multirow[b]{2}{*}{ Sons } & \multirow[b]{2}{*}{ Daus } & \multicolumn{2}{|l|}{ Before } & \multirow{2}{*}{$\begin{array}{c}\text { After } \\
\text { Bros }\end{array}$} & \multirow[b]{2}{*}{ Sis } & \multirow{2}{*}{$\begin{array}{c}\text { Sons } \\
\text { Sons }\end{array}$} & \multirow[b]{2}{*}{ Daus } & \multicolumn{2}{|c|}{ Daughters } & \multicolumn{2}{|c|}{ Brothers } & \multicolumn{2}{|l|}{ Sisters } & \\
\hline & & & & & & & Bros & Sis & & & & & Sons & Daus & Sons & Daus & Sons & Daus & \\
\hline 65 & 10.34 & D & $\mathbf{F}$ & $\mathbf{S}$ & 2 & 1 & 0 & 0 & 1 & 0 & 0 & 0 & 0 & 0 & 0 & 0 & 0 & 0 & \\
\hline 66 & 1.35 & $\mathrm{NI}^{*}$ & - & D & 0 & 1 & 0 & 0 & 2 & 4 & 0 & 0 & 0 & 0 & 0 & 1 & 2 & 3 & \\
\hline 67 & 5.35 & NI & D & $\overline{\mathbf{D}}$ & 1 & 1 & 0 & 0 & 0 & $i$ & 0 & 0 & 0 & 0 & 0 & 0 & 0 & 0 & \\
\hline 68 & 6.35 & $D^{*}$ & - & $\bar{S}$ & 0 & 2 & 1 & 3 & 0 & 0 & 0 & 0 & 0 & 0 & 0 & 3 & 0 & 2 & \\
\hline 69 & 7.35 & $\mathrm{D}^{*}$ & - & $\mathbf{S}$ & 1 & 2 & 0 & 0 & 1 & 0 & 0 & 0 & 0 & 0 & 1 & 1 & 0 & 0 & \\
\hline 71 & 8.35 & D & D & D & 0 & 3 & 1 & 0 & 0 & 0 & 0 & 0 & 0 & 0 & 0 & 1 & 0 & 0 & \\
\hline 72 & 10.35 & $D^{*}$ & - & $\mathbf{S}$ & 1 & 1 & 0 & $\begin{array}{l}0 \\
1 \mathrm{Lu}\end{array}$ & 0 & 0 & 0 & 0 & 0 & 0 & 0 & 0 & 0 & 0 & \\
\hline 73 & 12.35 & NI & $\mathbf{F}$ & D & 1 & 2 & 1 & $\begin{array}{l}1 \\
1 \mathrm{Lb} P\end{array}$ & $\begin{array}{l}2 \\
\text { r } 341\end{array}$ & 0 & 0 & 0 & 0 & 0 & 1 & 2 & 3 & 5 & \\
\hline 74 & 12.35 & NI & $\mathbf{D}$ & $\mathbf{D}$ & 2 & 0 & 0 & 1 & 0 & 0 & 0 & 0 & 0 & 0 & 0 & 0 & 1 & 1 & \\
\hline 75 & 1.36 & $\mathrm{NI}^{*}$ & - & $\mathbf{S}$ & 1 & $\begin{array}{l}0 \\
2\end{array}$ & 0 & 0 & 0 & 1 & 0 & 0 & 0 & 0 & 0 & 0 & 1 & 1 & \\
\hline 76 & 5.36 & $D^{*}$ & - & $\mathbf{S}$ & 0 & 2 & 1 & 0 & 0 & 1 & 0 & 0 & 0 & 0 & 0 & 0 & $\mathbf{0}$ & 0 & \\
\hline 78 & 1.37 & $D^{*}$ & - & $\mathbf{S}$ & 3 & 0 & 1 & 2 & 0 & 1 & 0 & 0 & 0 & 0 & 1 & 0 & 7 & 0 & \\
\hline 79 & 2.37 & $\mathbf{D}^{*}$ & - & D & 2 & 1 & 0 & 0 & 0 & 1 & 0 & 0 & 0 & 0 & 0 & 0 & 2 & 0 & Mo Bro Son Lu \\
\hline 80 & 4.37 & $\bar{D}^{*}$ & - & $\overline{\mathbf{D}}$ & 1 & 3 & 0 & 0 & 0 & 0 & 0 & 0 & 0 & 0 & 0 & 0 & 0 & 0 & \\
\hline 81 & 5.37 & $\mathrm{D}^{*}$ & - & $\mathbf{D}$ & 0 & & 0 & 0 & 0 & 1 & 0 & 0 & 0 & 0 & 0 & 0 & 1 & 3 & \\
\hline 82 & 5.37 & $\mathbf{D}^{*}$ & - & $\mathbf{D}$ & 3 & 0 & 0 & 1 & 0 & 0 & 0 & 0 & 0 & 0 & 0 & 0 & 1 & 1 & \\
\hline 83 & 9.37 & $\mathrm{NI}^{*}$ & - & $\mathbf{D}$ & 1 & $1 \mathrm{LPb}$ & 0 & 0 & 0 & 0 & 0 & 0 & 0 & 0 & 0 & 0 & 0 & 0 & \\
\hline 84 & 1.38 & $\mathbf{D}^{*}$ & - & $\mathbf{D}$ & 1 & 1 & 1 & 0 & 0 & 0 & 0 & 0 & 0 & 0 & 2 & 1 & 0 & 0 & \\
\hline 85 & 2.38 & $\mathrm{NI}^{*}$ & - & $\mathbf{S}$ & 1 & 0 & 0 & 0 & $\mathbf{0}$ & 1 & 0 & 0 & 0 & 0 & 0 & 0 & 1 & 1 & $\begin{array}{l}\text { Fa Si LPu } \\
\text { Fa Fa Si Lu }\end{array}$ \\
\hline 86 & 8.38 & $D^{*}$ & - & D & 0 & 2 & 0 & 0 & 0 & 0 & $\mathbf{0}$ & 0 & 0 & 0 & 0 & 0 & 0 & 0 & Mo Fa Si P \\
\hline 87 & 8.38 & $\bar{D}^{*}$ & - & $\bar{D}$ & 0 & 2 & 1 & 0 & 0 & 1 & 0 & 0 & 0 & 0 & 0 & 1 & 0 & 0 & \\
\hline 88 & 12.38 & $D^{*}$ & - & D & 1 & 1 & 0 & 0 & 0 & 0 & 0 & 0 & 0 & 0 & 0 & 0 & 0 & 0 & \\
\hline 89 & 3.39 & $\mathrm{NI}^{*}$ & - & $\vec{D}$ & 1 & 2 & 0 & 1 & 0 & 0 & 0 & 0 & 0 & 0 & 0 & 0 & 1 & 1 & \\
\hline 90 & 9.39 & NI & $\mathbf{F}$ & $\mathbf{F}$ & 0 & 2 & 1 & 0 & 0 & 1 & 0 & 0 & 0 & 0 & 0 & 0 & 0 & 0 & \\
\hline
\end{tabular}

GROUP II: CLb

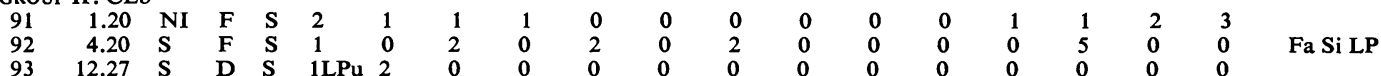

GROUP III: CLCPu

$\begin{array}{rrllll}94 & 8.12 & \text { NI } & \text { D } & \text { D } & 1 \\ 95 & 5.14 & \text { NI } & \text { D } & \text { D } & 1 \\ 96 & 5.15 & \text { NI } & \text { F } & \text { F } & 1 \\ 97 & 4.16 & \text { S } & \text { D } & \text { D } & 1 \\ 98 & 8.16 & \text { NI } & \text { D } & \text { D } & 1 \\ 99 & 10.17 & \text { NI } & \text { F } & \text { S } & 4 \\ 100 & 1.19 & \text { D } & \text { D } & \text { F } & 0 \\ 101 & 6.19 & \text { NI } & \text { D } & \text { D } & 2 \\ 102 & 7.19 & \text { NI } & \text { D } & \text { D } & 0 \\ 103 & 12.19 & \text { NI } & \text { F } & \text { S } & 0 \\ 104 & 4.20 & \text { NI } & \text { D } & \text { S } & 2 \\ 105 & 4.20 & \text { D } & \text { F } & \text { S } & 2 \\ 106 & 6.20 & \text { NI } & \text { F } & \text { F } & 0 \\ 107 & 9.20 & \text { NI } & \text { F } & \text { S } & 1 \\ 108 & 1.21 & \text { D } & \text { F } & \text { D } & 1 \\ 109 & 3.21 & \text { D } & \text { F } & \text { S } & 1 \\ & & & & & \\ 110 & 3.21 & \text { D } & \text { D } & \text { S } & 1 \\ & & & & & \\ 111 & 3.21 & \text { NI } & \text { F } & \text { S } & 0 \\ 112 & 6.21 & \text { NI } & \text { F } & \text { F } & 1 \\ 113 & 9.21 & \text { NI } & \text { F } & \text { S } & 1 \\ 114 & 9.21 & \text { D } & - & - & 1 \\ 115 & 9.21 & \text { NI } & \text { D } & \text { D } & 3 \\ 116 & 11.21 & \text { D } & \text { F } & \text { S } & 1 \\ 117 & 3.22 & \text { D } & \text { F } & \text { S } & 2 \\ 118 & 5.22 & \text { D } & \text { D } & \text { S } & 0 \\ 119 & 1.23 & \text { NI } & \text { D } & \text { D } & 2 \\ 120 & 1.23 & \text { NI } & \text { D } & \text { D } & 0 \\ 121 & 2.23 & \text { NI } & \text { F } & \text { D } & 1 \\ 122 & 2.23 & \text { NI } & \text { F } & \text { D } & 0 \\ 123 & 6.23 & \text { D } & \text { D } & \text { D } & 1\end{array}$

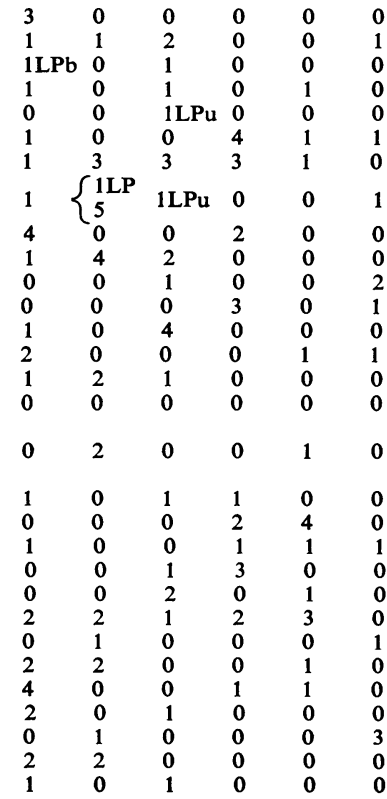

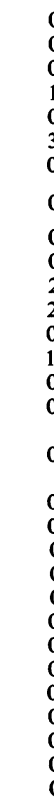
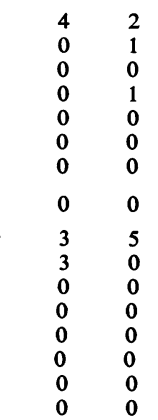

$\begin{array}{ll}0 \\ 1 \\ 0 \\ 0 \\ 0 \\ 1 & 0 \\ 2 & \\ 0 & \\ 0 & \\ 0 & \\ 9 & \\ 0 & \\ 2 & 2 \\ 0 & 0 \\ 0 & 0 \\ 1 & 3 \\ 0 & 0\end{array}$

$\begin{array}{ll}0 & 0 \\ 0 & 1 \\ 0 & 0 \\ 0 & 0 \\ 0 & 0 \\ 0 & 0 \\ 0 & 2 \\ 0 & 0 \\ 2 & 1 \\ 2 & 3 \\ 0 & 0 \\ 0 & 0 \\ 1 \mathrm{Lu} & 2 \\ 1 & 0\end{array}$

2
0
2
0
3
0
3
0
3
1
0
0
2
0

$\begin{array}{cc}\text { 1Lu } & \\ 4 & 0 \\ 0 & 0 \\ 2 & 4 \\ 0 & 0 \\ 0 & 0 \\ 0 & 3 \\ 4 & 2 \\ 0 & 0 \\ 1 & 0 \\ 0 & 2 \\ 0 & 1 \\ 0 & 0 \\ 3 & 0 \\ 0 & \end{array}$

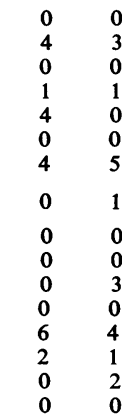

Fa Si P

Fa Mo Bro LP

$$
1
$$$$
\text { (a) }
$$$$
\mathbf{0}
$$

Mo Mo Si Lu

Fa Si LPu

Fa Lu

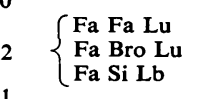


APPENDIX-continued

\begin{tabular}{|c|c|c|c|c|c|c|c|c|c|c|c|c|c|c|c|c|c|c|c|}
\hline \multirow{3}{*}{$\begin{array}{l}\text { Serial } \\
\text { No }\end{array}$} & \multirow{3}{*}{$\begin{array}{l}\begin{array}{l}\text { Month } \\
\text { and } \\
\text { year of } \\
\text { birth }\end{array} \\
7.23 \\
2.24\end{array}$} & \multirow{2}{*}{\multicolumn{3}{|c|}{$\begin{array}{l}\text { Method } \\
\text { traced in } \\
1958 / 73 / 78\end{array}$}} & \multicolumn{2}{|c|}{ Children } & \multicolumn{4}{|c|}{ Sibs (excluding twins) } & \multicolumn{4}{|c|}{ Grandchildren } & \multicolumn{4}{|c|}{ Nephews and nieces } & \multirow{2}{*}{$\begin{array}{l}\text { Other affected } \\
\text { relatives } \\
\text { and spouses }\end{array}$} \\
\hline & & & & & Sons & Daus & $\begin{array}{l}\text { Before } \\
\text { Bros }\end{array}$ & Sis & $\begin{array}{l}\text { After } \\
\text { Bros }\end{array}$ & Sis & $\begin{array}{l}\text { Sons } \\
\text { Sons }\end{array}$ & Daus & \multicolumn{2}{|c|}{$\begin{array}{l}\text { Daughters } \\
\text { Sons Daus }\end{array}$} & \multicolumn{2}{|c|}{ Brothers } & $\begin{array}{l}\text { Sisters } \\
\text { Sons }\end{array}$ & Daus & \\
\hline & & $\begin{array}{l}\text { D } \\
\text { NI }\end{array}$ & $\begin{array}{l}\mathbf{D} \\
\mathbf{F}\end{array}$ & $\begin{array}{l}\mathbf{D} \\
\mathbf{S}\end{array}$ & $\begin{array}{l}1 \\
0\end{array}$ & $\begin{array}{l}0 \\
1\end{array}$ & $\begin{array}{l}1 \\
0\end{array}$ & $\begin{array}{l}0 \\
0\end{array}$ & $\begin{array}{l}0 \\
1\end{array}$ & $\begin{array}{l}0 \\
0\end{array}$ & $\begin{array}{l}0 \\
0\end{array}$ & $\begin{array}{l}0 \\
0\end{array}$ & $\begin{array}{l}0 \\
0\end{array}$ & & $\begin{array}{l}0 \\
2\end{array}$ & $\begin{array}{l}0 \\
1\end{array}$ & $\begin{array}{l}0 \\
0\end{array}$ & $\begin{array}{l}0 \\
0\end{array}$ & \\
\hline 126 & 5.24 & NI & $\mathbf{D}$ & & $\begin{array}{l}1 \mathrm{Lu} \\
3\end{array}$ & 2 & 0 & 0 & 0 & 1 & 0 & 0 & 0 & $\mathbf{0}$ & 0 & $\mathbf{0}$ & 2 & 3 & \\
\hline $\begin{array}{l}127 \\
128 \\
129 \\
130 \\
131 \\
132 \\
133 \\
134 \\
135 \\
136 \\
137 \\
138 \\
139 \\
140 \\
141 \\
142 \\
143 \\
144\end{array}$ & $\begin{array}{r}8.24 \\
12.24 \\
1.25 \\
1.25 \\
1.25 \\
4.25 \\
4.25 \\
4.25 \\
6.25 \\
6.25 \\
7.25 \\
7.25 \\
7.25 \\
9.25 \\
10.25 \\
12.25 \\
2.26 \\
5.26\end{array}$ & $\begin{array}{l}\text { D } \\
\text { D } \\
\mathbf{D} \\
\mathbf{D} \\
\mathbf{D} \\
\mathbf{N I} \\
\mathbf{N I} \\
\mathbf{N I} \\
\mathbf{D} \\
\mathbf{N I} \\
\mathbf{N I}^{*} \\
\mathbf{D} \\
\mathbf{D} \\
\mathbf{D} \\
\mathbf{N I} \\
\mathbf{D} \\
\mathbf{D} \\
\mathbf{N I}\end{array}$ & $\begin{array}{l}\text { F } \\
\text { F } \\
\mathbf{D} \\
\mathbf{D} \\
\mathbf{D} \\
\mathbf{D} \\
\mathbf{F} \\
\mathbf{F} \\
\mathbf{D} \\
- \\
\mathbf{F} \\
\mathbf{D} \\
- \\
\mathbf{D} \\
\mathbf{D} \\
\mathbf{D} \\
\mathbf{D} \\
\mathbf{D}\end{array}$ & $\begin{array}{l}\text { S } \\
\text { S } \\
\mathbf{D} \\
\mathbf{D} \\
\mathbf{D} \\
\mathbf{D} \\
\mathbf{S} \\
\mathbf{S} \\
\mathbf{D} \\
\mathbf{S} \\
\mathbf{S} \\
\mathbf{D} \\
\mathbf{S} \\
\mathbf{D} \\
\mathbf{D} \\
\mathbf{D} \\
\mathbf{S} \\
\mathbf{D}\end{array}$ & $\begin{array}{l}2 \\
0 \\
0 \\
1 \\
1 \\
2 \\
1 \\
2 \\
0 \\
1 \\
1 \\
3 \\
2 \\
2 \\
0 \\
0 \\
0 \\
1\end{array}$ & $\begin{array}{l}0 \\
2 \\
2 \\
1 \\
1 \\
0 \\
1 \\
3 \\
2 \\
0 \\
0 \\
0 \\
1 \\
1 \\
2 \\
1 \\
2 \\
1\end{array}$ & $\begin{array}{l}1 \\
0 \\
1 \\
2 \\
0 \\
0 \\
2 \\
1 \\
1 \\
0 \\
0 \\
1 \\
1 \\
1 \\
0 \\
1 \\
0\end{array}$ & $\begin{array}{l}0 \\
1 \\
0 \\
1 \\
0 \\
0 \\
1 \\
1 \\
0 \\
0 \\
0 \\
0 \\
0 \\
5 \\
0 \\
4 \\
1 \\
0\end{array}$ & $\begin{array}{l}3 \\
1 \\
0 \\
0 \\
0 \\
2 \\
0 \\
1 \\
0 \\
0 \\
1 \\
0 \\
1 \\
0 \\
0 \\
0 \\
0 \\
2\end{array}$ & $\begin{array}{l}0 \\
0 \\
0 \\
0 \\
0 \\
4 \\
0 \\
0 \\
0 \\
0 \\
0 \\
0 \\
0 \\
0 \\
2 \\
0 \\
0 \\
2\end{array}$ & $\begin{array}{l}0 \\
0 \\
0 \\
0 \\
1 \\
0 \\
0 \\
0 \\
0 \\
0 \\
0 \\
0 \\
0 \\
0 \\
0 \\
0 \\
0 \\
1\end{array}$ & $\begin{array}{l}0 \\
0 \\
0 \\
0 \\
0 \\
0 \\
0 \\
0 \\
0 \\
0 \\
0 \\
0 \\
0 \\
0 \\
0 \\
0 \\
0 \\
0\end{array}$ & $\begin{array}{l}0 \\
0 \\
0 \\
0 \\
0 \\
0 \\
0 \\
2 \\
0 \\
0 \\
0 \\
0 \\
0 \\
0 \\
2 \\
3 \\
3 \\
0\end{array}$ & $\begin{array}{l}0 \\
0 \\
0 \\
0 \\
0 \\
0 \\
0 \\
2 \\
1 \\
0 \\
0 \\
0 \\
0 \\
1 \\
2 \\
0 \\
3 \\
0\end{array}$ & $\begin{array}{l}1 \\
1 \\
2 \\
1 \\
0 \\
1 \\
1 \\
0 \\
1 \\
0 \\
0 \\
0 \\
2 \\
1 \\
0 \\
0 \\
0 \\
0\end{array}$ & $\begin{array}{l}4 \\
1 \\
0 \\
3 \\
0 \\
1 \\
0 \\
0 \\
2 \\
0 \\
2 \\
1 \\
0 \\
1 \\
0 \\
0 \\
0 \\
0\end{array}$ & $\begin{array}{r}0 \\
2 \\
0 \\
2 \\
0 \\
3 \\
0 \\
2 \\
0 \\
0 \\
0 \\
0 \\
0 \\
11 \\
1 \\
6 \\
2 \\
1\end{array}$ & $\begin{array}{l}0 \\
1 \\
0 \\
0 \\
0 \\
6 \\
0 \\
0 \\
0 \\
0 \\
0 \\
0 \\
0 \\
6 \\
3 \\
4 \\
5 \\
1\end{array}$ & Mo Bro Son Lu \\
\hline 145 & 7.26 & NI & $\mathbf{F}$ & $\mathbf{S}$ & 1 & 0 & 0 & $\mathbf{0}$ & $\mathbf{0}$ & $1 \mathrm{Lu}$ & 0 & 2 & 0 & 0 & 0 & 0 & 0 & 0 & $\left\{\begin{array}{l}\text { Mo Lu } \\
\text { Mo Bro LP }\end{array}\right.$ \\
\hline $\begin{array}{l}146 \\
147\end{array}$ & $\begin{array}{r}7.26 \\
10.26\end{array}$ & $\begin{array}{l}\text { NI } \\
\text { D }\end{array}$ & $\begin{array}{l}\mathbf{F} \\
\mathbf{F}\end{array}$ & $\begin{array}{l}\mathbf{S} \\
\mathbf{S}\end{array}$ & $\begin{array}{l}0 \\
1\end{array}$ & $\left\{\begin{array}{l}2 \\
1 \mathrm{LPu} \\
1\end{array}\right.$ & $\begin{array}{l}0 \\
0\end{array}$ & $\begin{array}{l}0 \\
0\end{array}$ & $\begin{array}{l}1 \\
1\end{array}$ & $\left\{\begin{array}{l}0 \\
1 \\
1 \mathrm{LPb}\end{array}\right.$ & $\begin{array}{c}0 \\
0 \\
\text { Pr } 408\end{array}$ & $\begin{array}{c}0 \\
1\end{array}$ & $\left\{\begin{array}{l}0 \\
1 \mathrm{LPb} \\
1\end{array}\right.$ & 1 & $\begin{array}{l}0 \\
0\end{array}$ & $\begin{array}{l}0 \\
0\end{array}$ & $\begin{array}{l}0 \\
0\end{array}$ & $\begin{array}{l}0 \\
4\end{array}$ & \\
\hline 148 & 12.26 & $\mathbf{N I}$ & D & $\mathbf{D}$ & 1 & 1 & 0 & 0 & 0 & 0 & 0 & 0 & $\mathbf{0}$ & 0 & 0 & $\mathbf{0}$ & $\mathbf{0}$ & 0 & $\left\{\begin{array}{l}\text { Mo Bro Son } \\
\text { LPb }\end{array}\right.$ \\
\hline $\begin{array}{l}149 \\
150 \\
151 \\
152 \\
153 \\
154 \\
155 \\
156 \\
157 \\
158 \\
159 \\
160 \\
161\end{array}$ & $\begin{array}{r}2.27 \\
3.27 \\
3.27 \\
6.27 \\
8.27 \\
9.27 \\
9.27 \\
10.27 \\
12.27 \\
12.27 \\
3.28 \\
3.28 \\
3.28 \\
\end{array}$ & 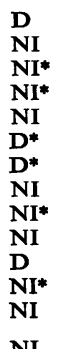 & $\begin{array}{l}\text { F } \\
\text { D } \\
- \\
\bar{F} \\
- \\
\bar{F} \\
\text { F } \\
\bar{D} \\
\text { D } \\
\bar{F} \\
\end{array}$ & $\begin{array}{l}\text { S } \\
\text { S } \\
\mathbf{D} \\
\mathbf{D} \\
\mathbf{S} \\
\mathbf{S} \\
\mathbf{D} \\
\mathbf{S} \\
\mathbf{S} \\
\mathbf{D} \\
\mathbf{D} \\
\mathbf{D} \\
\mathbf{F} \\
\end{array}$ & $\begin{array}{l}2 \\
1 \\
0 \\
0 \\
2 \\
2 \\
0 \\
1 \\
2 \\
0 \\
0 \\
2 \\
1 \\
1 \mathrm{Lu}\end{array}$ & $\begin{array}{l}1 \\
2 \\
2 \\
2 \\
2 \\
1 \\
1 \\
0 \\
2 \\
2 \\
2 \\
3 \\
1 \\
1\end{array}$ & $\begin{array}{l}0 \\
1 \\
7 \\
2 \\
0 \\
0 \\
0 \\
0 \\
0 \\
0 \\
5 \\
0 \\
0 \\
1\end{array}$ & $\begin{array}{l}0 \\
0 \\
1 \\
2 \\
0 \\
1 \\
0 \\
0 \\
1 \\
0 \\
3 \\
0 \\
0 \\
0\end{array}$ & $\begin{array}{l}1 \\
1 \\
1 \\
2 \\
1 \\
0 \\
0 \\
1 \\
0 \\
0 \\
0 \\
2 \\
0 \\
0\end{array}$ & $\begin{array}{l}0 \\
0 \\
0 \\
4 \\
0 \\
0 \\
0 \\
0 \\
0 \\
0 \\
1 \\
2 \\
0 \\
0\end{array}$ & $\begin{array}{l}0 \\
0 \\
0 \\
0 \\
0 \\
0 \\
0 \\
1 \\
0 \\
0 \\
0 \\
0 \\
0 \\
0\end{array}$ & $\begin{array}{l}0 \\
0 \\
0 \\
0 \\
0 \\
0 \\
0 \\
0 \\
0 \\
0 \\
0 \\
0 \\
0 \\
0\end{array}$ & $\begin{array}{l}0 \\
0 \\
0 \\
0 \\
1 \\
0 \\
0 \\
0 \\
0 \\
0 \\
0 \\
0 \\
0 \\
0\end{array}$ & $\begin{array}{l}0 \\
0 \\
0 \\
0 \\
1 \\
0 \\
0 \\
0 \\
0 \\
0 \\
1 \\
0 \\
0 \\
0\end{array}$ & $\begin{array}{l}0 \\
2 \\
7 \\
2 \\
0 \\
0 \\
0 \\
0 \\
0 \\
0 \\
5 \\
4 \\
0 \\
1\end{array}$ & $\begin{array}{l}1 \\
4 \\
3 \\
2 \\
0 \\
0 \\
0 \\
0 \\
0 \\
0 \\
5 \\
0 \\
0 \\
1\end{array}$ & $\begin{array}{l}\mathbf{0} \\
0 \\
3 \\
3 \\
0 \\
1 \\
0 \\
0 \\
0 \\
0 \\
1 \\
3 \\
0 \\
0\end{array}$ & $\begin{array}{l}0 \\
0 \\
1 \\
1 \\
0 \\
1 \\
0 \\
0 \\
1 \\
0 \\
4 \\
2 \\
0 \\
0\end{array}$ & Mo Si Son Lu \\
\hline 162 & 3.28 & NI & $\mathbf{F}$ & $\mathbf{S}$ & 1 & & & & & & & & & & & & & & \\
\hline $\begin{array}{l}163 \\
164 \\
165 \\
166 \\
167 \\
168 \\
169 \\
170 \\
171 \\
172 \\
173 \\
174 \\
175 \\
176\end{array}$ & $\begin{array}{r}4.28 \\
9.28 \\
11.28 \\
1.29 \\
2.29 \\
7.29 \\
8.29 \\
8.29 \\
8.29 \\
10.29 \\
10.29 \\
10.29 \\
11.29 \\
12.29\end{array}$ & $\begin{array}{l}\text { NI } \\
\text { NI } \\
\text { NI } \\
\text { NI } \\
\text { NI } \\
\mathbf{D} \\
\mathbf{D} \\
\mathbf{D} \\
\mathbf{D}^{*} \\
\mathbf{D}^{*} \\
\mathbf{S}^{*} \\
\mathbf{N I}^{\mathbf{N}} \\
\mathbf{N I}^{*} \\
\text { NI }\end{array}$ & $\begin{array}{l}\mathbf{D} \\
\mathbf{D} \\
\mathbf{D} \\
\mathbf{F} \\
\mathbf{F} \\
\mathbf{D} \\
\mathbf{D} \\
\mathbf{D} \\
- \\
- \\
- \\
\mathbf{F} \\
- \\
\mathbf{D}\end{array}$ & $\begin{array}{l}\text { D } \\
\text { D } \\
\text { D } \\
\text { S } \\
\text { S } \\
\text { D } \\
\text { D } \\
\text { D } \\
\text { D } \\
\text { S } \\
\text { D } \\
\text { S } \\
\text { D } \\
\text { S }\end{array}$ & $\begin{array}{l}1 \\
0 \\
0 \\
2 \\
2 \\
0 \\
2 \\
2 \\
0 \\
0 \\
0 \\
2 \\
1 \\
3\end{array}$ & $\begin{array}{l}0 \\
3 \\
2 \\
2 \\
0 \\
2 \\
1 \\
1 \\
1 \\
2 \\
1 \\
2 \\
0 \\
0\end{array}$ & $\begin{array}{l}0 \\
1 \\
1 \\
1 \\
4 \\
0 \\
0 \\
0 \\
2 \\
0 \\
1 \\
1 \\
0 \\
0\end{array}$ & $\begin{array}{l}0 \\
0 \\
0 \\
0 \\
1 \\
0 \\
2 \\
0 \\
2 \\
1 \\
0 \\
2 \\
0 \\
0\end{array}$ & $\begin{array}{l}4 \\
0 \\
0 \\
0 \\
0 \\
1 \\
0 \\
1 \\
0 \\
1 \\
0 \\
0 \\
0 \\
2\end{array}$ & $\begin{array}{l}2 \\
1 \\
0 \\
1 \\
0 \\
1 \\
1 \\
2 \\
0 \\
1 \\
0 \\
1 \\
0 \\
0\end{array}$ & $\begin{array}{l}0 \\
0 \\
0 \\
0 \\
0 \\
0 \\
1 \\
0 \\
0 \\
0 \\
0 \\
0 \\
0 \\
1\end{array}$ & $\begin{array}{l}0 \\
0 \\
0 \\
0 \\
0 \\
0 \\
0 \\
0 \\
0 \\
0 \\
0 \\
0 \\
0 \\
1\end{array}$ & $\begin{array}{l}0 \\
0 \\
0 \\
0 \\
0 \\
0 \\
1 \\
0 \\
0 \\
0 \\
0 \\
0 \\
0 \\
0\end{array}$ & $\begin{array}{l}0 \\
1 \\
0 \\
0 \\
0 \\
0 \\
2 \\
0 \\
0 \\
0 \\
0 \\
0 \\
0 \\
0\end{array}$ & $\begin{array}{l}0 \\
0 \\
1 \\
0 \\
2 \\
0 \\
0 \\
0 \\
1 \\
1 \\
0 \\
0 \\
0 \\
0\end{array}$ & $\begin{array}{l}1 \\
2 \\
1 \\
4 \\
4 \\
0 \\
0 \\
0 \\
2 \\
1 \\
2 \\
0 \\
0 \\
0\end{array}$ & $\begin{array}{l}0 \\
1 \\
0 \\
0 \\
2 \\
2 \\
4 \\
0 \\
0 \\
4 \\
0 \\
1 \\
0 \\
0\end{array}$ & $\begin{array}{l}1 \\
1 \\
0 \\
2 \\
1 \\
0 \\
3 \\
1 \\
1 \\
3 \\
0 \\
2 \\
0 \\
0\end{array}$ & \\
\hline 177 & 7.30 & $D^{*}$ & - & D & $\mathbf{0}$ & $\left\{\begin{array}{l}1 \mathrm{LPu} \\
1\end{array}\right.$ & 1 & 0 & 0 & $\mathbf{0}$ & 0 & 0 & 0 & 0 & 0 & 0 & 0 & 0 & \\
\hline $\begin{array}{l}178 \\
179\end{array}$ & $\begin{array}{r}9.30 \\
10.30\end{array}$ & $\begin{array}{l}\text { NI } \\
\text { D }\end{array}$ & $\begin{array}{l}\mathbf{D} \\
\mathbf{F}\end{array}$ & $\begin{array}{l}\mathbf{S} \\
\mathbf{S}\end{array}$ & 1 & 1 & $\begin{array}{l}0 \\
1 \mathrm{LPu}\end{array}$ & $\begin{array}{l}2 \\
1\end{array}$ & $\begin{array}{l}2 \\
0\end{array}$ & $\begin{array}{l}0 \\
0\end{array}$ & $\begin{array}{l}0 \\
0\end{array}$ & $\begin{array}{l}\mathbf{0} \\
\mathbf{0}\end{array}$ & $\begin{array}{l}\mathbf{0} \\
\mathbf{0}\end{array}$ & $\begin{array}{l}0 \\
0\end{array}$ & $\begin{array}{l}0 \\
0\end{array}$ & $\begin{array}{l}\mathbf{0} \\
\mathbf{0}\end{array}$ & $\begin{array}{l}5 \\
2\end{array}$ & $\begin{array}{l}5 \\
0\end{array}$ & \\
\hline 180 & 10.30 & $\mathbf{D}^{*}$ & 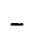 & & 1 & 1 & 1 & 0 & 0 & 0 & 0 & 0 & 0 & 0 & 0 & 0 & 0 & 0 & \\
\hline $\begin{array}{l}181 \\
182 \\
183 \\
184\end{array}$ & $\begin{array}{l}1.31 \\
3.31 \\
3.31 \\
3.31\end{array}$ & $\begin{array}{l}\text { NI } \\
\mathbf{D} \\
\mathbf{D}^{*} \\
\mathbf{D}\end{array}$ & $\begin{array}{l}\text { F } \\
\mathbf{D} \\
\overline{\mathbf{D}}\end{array}$ & $\begin{array}{l}\text { S } \\
\mathbf{D} \\
\mathbf{S} \\
\mathbf{D}\end{array}$ & $\begin{array}{l}1 \\
2 \\
0 \\
1\end{array}$ & $\begin{array}{l}1 \\
1 \\
1 \\
1\end{array}$ & $\begin{array}{l}1 \\
0 \\
0 \\
0\end{array}$ & $\begin{array}{l}0 \\
0 \\
0 \\
0\end{array}$ & $\begin{array}{l}0 \\
1 \\
1 \\
0\end{array}$ & $\begin{array}{l}0 \\
1 \\
0 \\
0\end{array}$ & $\begin{array}{l}0 \\
1 \\
0 \\
0\end{array}$ & $\begin{array}{l}\mathbf{0} \\
0 \\
0 \\
0\end{array}$ & $\begin{array}{l}\mathbf{0} \\
\mathbf{0} \\
\mathbf{0} \\
\mathbf{0}\end{array}$ & $\begin{array}{l}1 \\
0 \\
0 \\
0\end{array}$ & $\begin{array}{l}0 \\
0 \\
1 \\
0\end{array}$ & $\begin{array}{l}0 \\
0 \\
1 \\
0\end{array}$ & $\begin{array}{l}0 \\
0 \\
0 \\
0\end{array}$ & $\begin{array}{l}0 \\
0 \\
0 \\
0\end{array}$ & \\
\hline 185 & 4.31 & $\mathbf{D}$ & $\mathbf{D}$ & D & $\left\{\begin{array}{l}1 \mathrm{LPu} \\
2\end{array}\right.$ & 1 & 1 & 2 & 0 & 1 & 0 & 0 & 0 & $\mathbf{0}$ & $\mathbf{0}$ & 0 & 3 & 2 & $\left\{\begin{array}{l}\text { Mo Si Lu } \\
\text { Mo Bro LPb } \\
\text { Fa Fa Fa L }\end{array}\right.$ \\
\hline $\begin{array}{l}186 \\
187\end{array}$ & $\begin{array}{l}6.31 \\
8.31\end{array}$ & $\begin{array}{l}\text { NI* } \\
\text { NI* }\end{array}$ & - & $\begin{array}{l}\mathbf{D} \\
\mathbf{S}\end{array}$ & $\begin{array}{l}2 \\
1\end{array}$ & $\begin{array}{l}0 \\
1\end{array}$ & $\begin{array}{l}0 \\
0\end{array}$ & $\begin{array}{l}1 \\
0\end{array}$ & $\begin{array}{l}1 \\
0\end{array}$ & $\begin{array}{l}0 \\
0\end{array}$ & $\begin{array}{l}0 \\
0\end{array}$ & $\begin{array}{l}0 \\
0\end{array}$ & $\begin{array}{l}0 \\
0\end{array}$ & $\begin{array}{l}0 \\
0\end{array}$ & $\begin{array}{l}0 \\
0\end{array}$ & $\begin{array}{l}0 \\
0\end{array}$ & $\begin{array}{l}0 \\
0\end{array}$ & $\begin{array}{l}0 \\
0\end{array}$ & \\
\hline
\end{tabular}




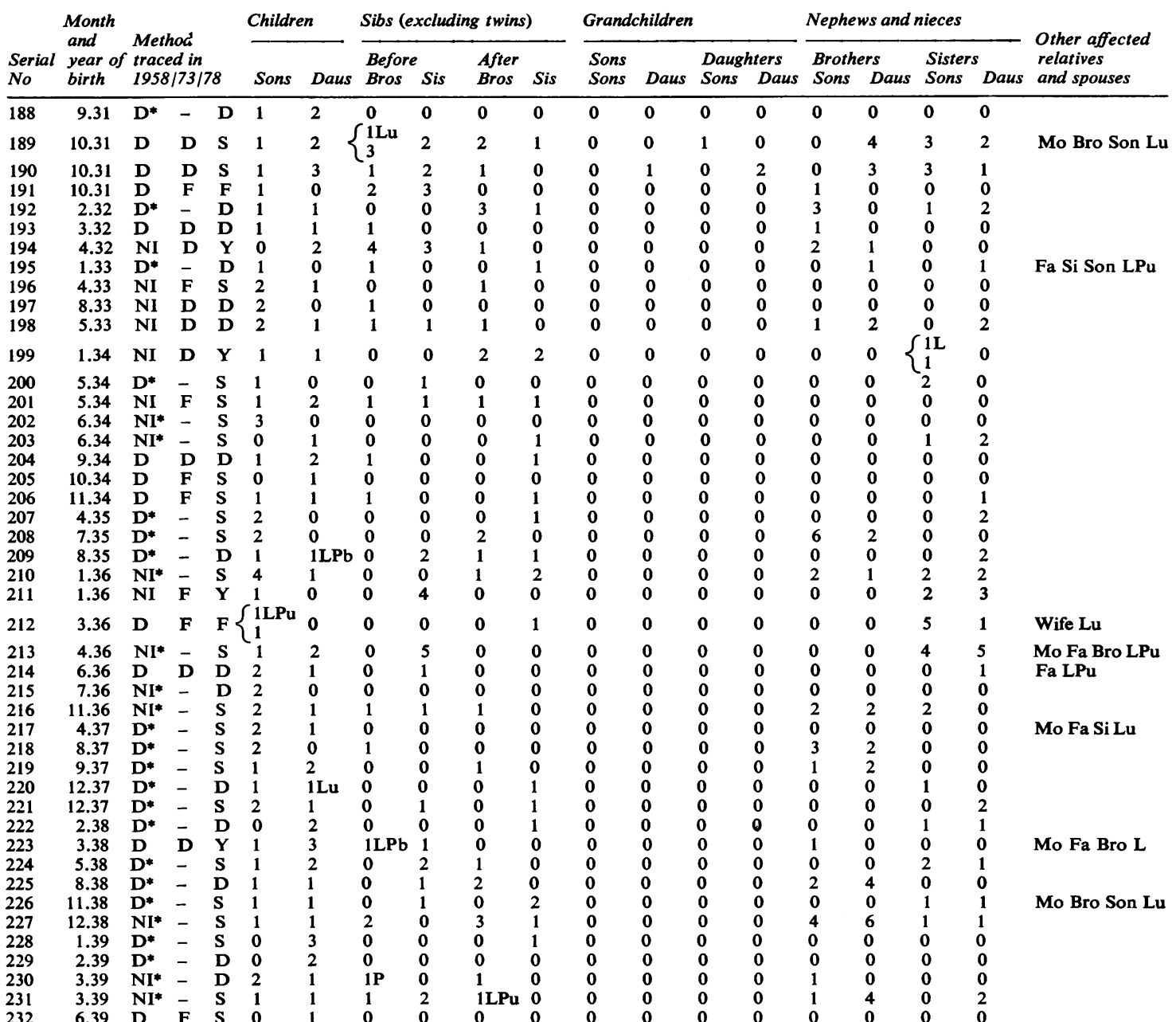

GROUP IV: CLCPb

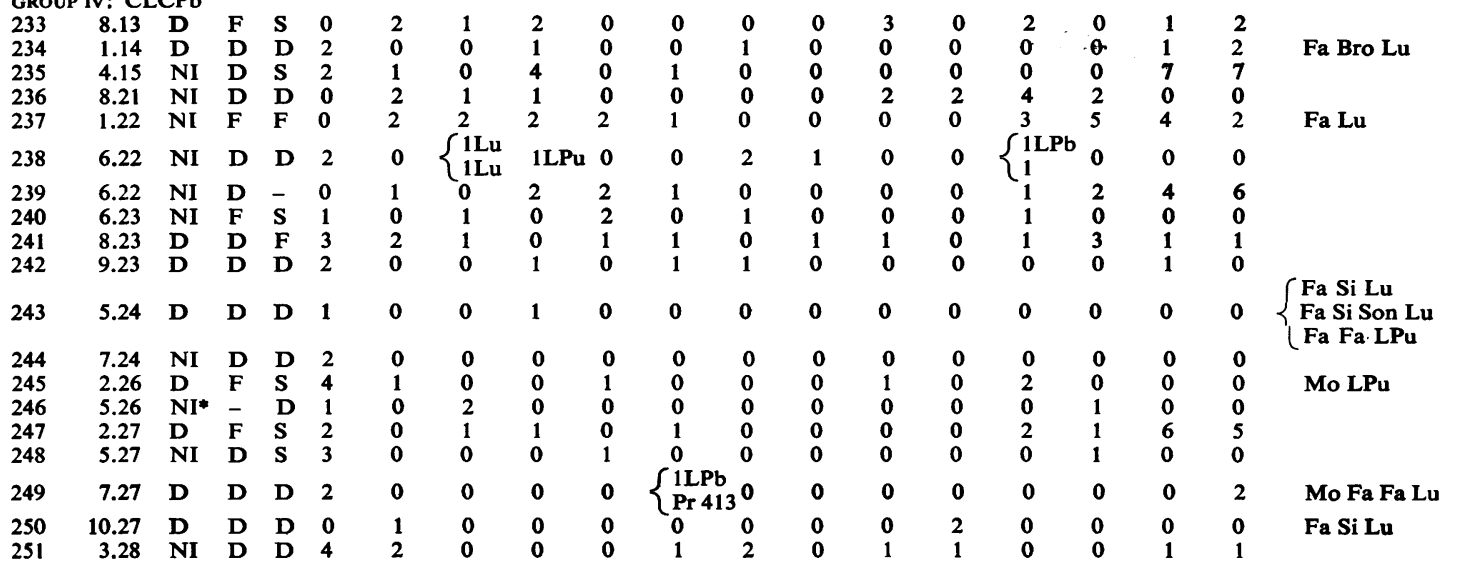


APPENDIX-continued

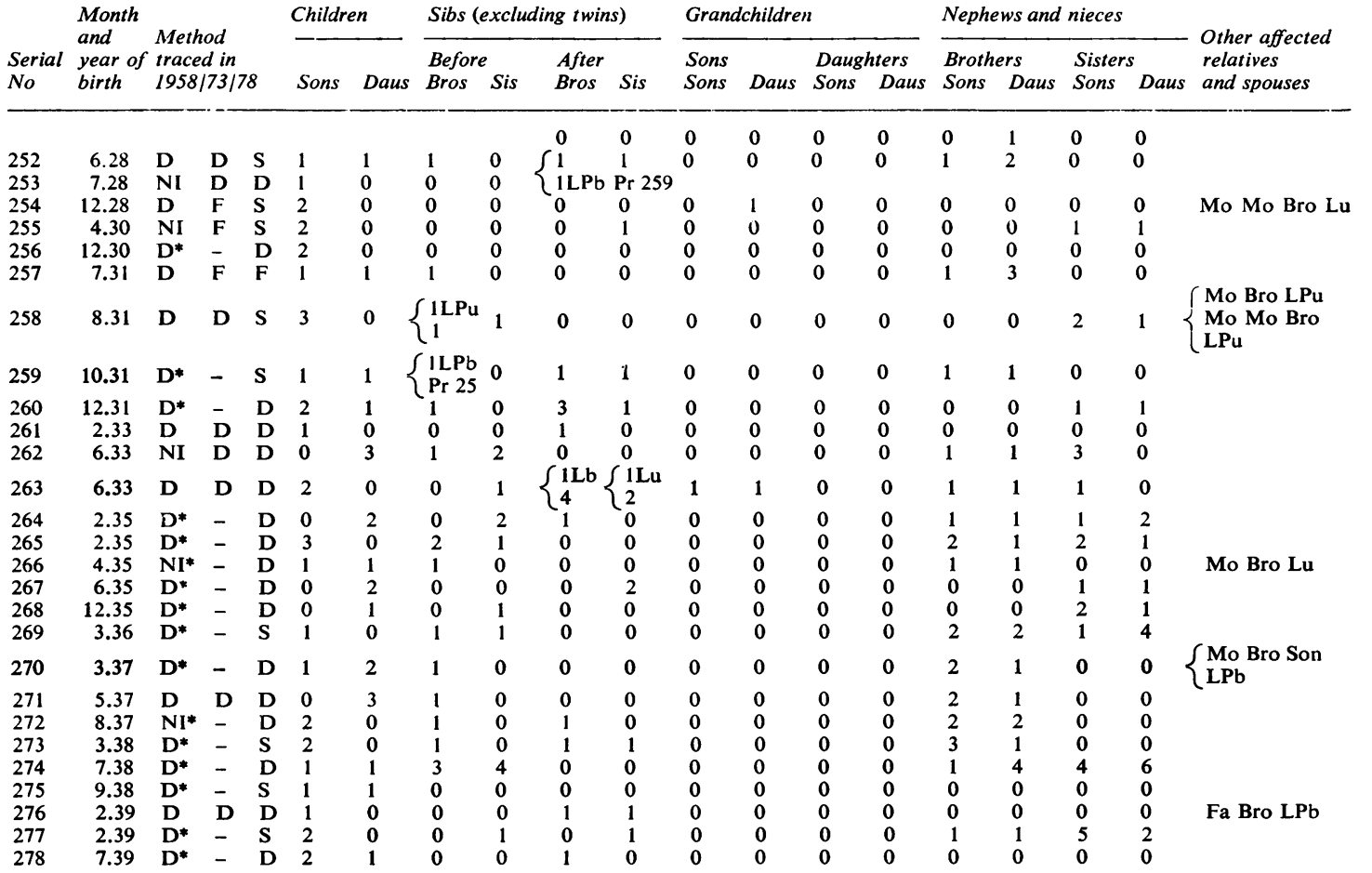

FEMALE

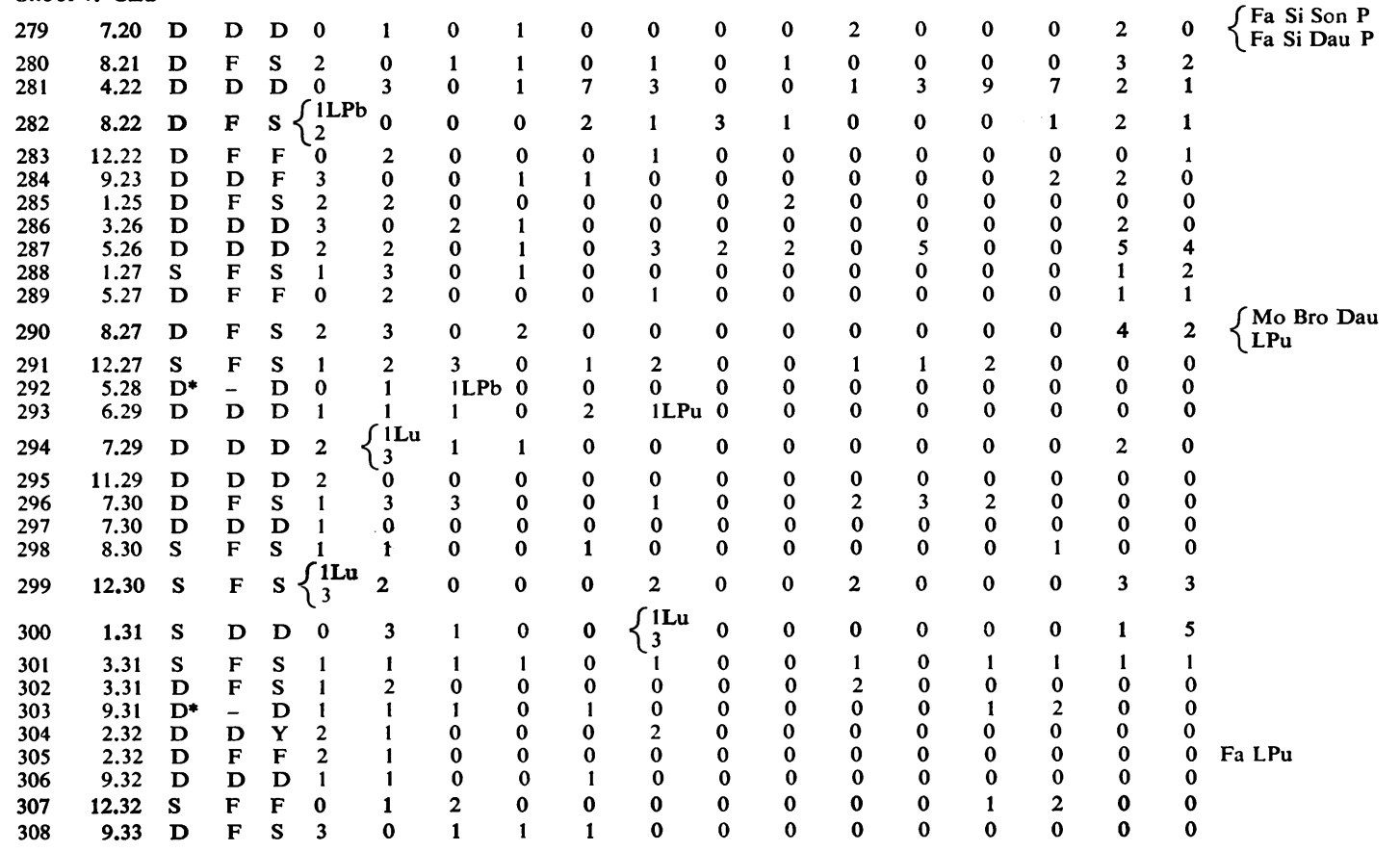


APPENDIX-continued

\begin{tabular}{|c|c|c|c|c|c|c|c|c|c|c|c|c|c|c|c|c|c|c|c|}
\hline \multirow[b]{2}{*}{$\begin{array}{l}\text { Serial } \\
\text { No }\end{array}$} & \multirow{2}{*}{$\begin{array}{l}\text { Month } \\
\text { and } \\
\text { year of } \\
\text { birth }\end{array}$} & \multirow{2}{*}{\multicolumn{3}{|c|}{$\begin{array}{l}\text { Method } \\
\text { traced in } \\
1958 / 73 / 78\end{array}$}} & \multicolumn{2}{|c|}{ Children } & \multicolumn{4}{|c|}{ Sibs (excluding twins) } & \multicolumn{4}{|c|}{ Grandchildren } & \multicolumn{4}{|c|}{ Nephews and nieces } & \multirow{2}{*}{$\begin{array}{l}\text { Other affected } \\
\text { relatives } \\
\text { and spouses }\end{array}$} \\
\hline & & & & & Sons & Daus & $\begin{array}{l}\text { Before } \\
\text { Bros }\end{array}$ & Sis & $\begin{array}{l}\text { After } \\
\text { Bros }\end{array}$ & Sis & $\begin{array}{l}\text { Sons } \\
\text { Sons }\end{array}$ & Daus & $\begin{array}{l}\text { Daugh } \\
\text { Sons }\end{array}$ & $\begin{array}{l}\text { hters } \\
\text { Daus }\end{array}$ & $\begin{array}{l}\text { Broth } \\
\text { Sons }\end{array}$ & Daus & $\begin{array}{l}\text { Sisters } \\
\text { Sons }\end{array}$ & Daus & \\
\hline 309 & 11.33 & $\mathbf{S}$ & D & D & 2 & 0 & 0 & 2 & $\mathbf{0}$ & $\left\{\begin{array}{l}1 \mathrm{Lu} \\
\operatorname{Pr} 324\end{array}\right.$ & $4^{0}$ & 0 & 0 & 0 & $\mathbf{0}$ & $\mathbf{0}$ & 1 & 1 & \\
\hline 310 & 12.33 & $\mathbf{D}$ & $\mathbf{F}$ & $\mathbf{F}$ & $\mathbf{0}$ & 2 & 0 & 1 & 0 & 0 & 0 & 0 & $\mathbf{0}$ & 0 & $\mathbf{0}$ & 0 & 3 & 2 & \\
\hline 311 & 12.33 & $\mathrm{NI}^{*}$ & - & $\mathbf{S}$ & 0 & 1 & 0 & 1 & 1 & 0 & 0 & 0 & 0 & 0 & 2 & 2 & 1 & 1 & \\
\hline 312 & 7.34 & $\mathrm{NI}^{*}$ & - & $\mathbf{D}$ & 1 & 0 & 3 & 1 & 3 & 3 & 0 & 0 & 0 & 0 & 2 & 6 & 6 & 5 & \\
\hline 313 & 2.35 & D & $\mathbf{D}$ & $\mathbf{D}$ & 3 & 0 & 0 & 0 & 1 & 0 & 0 & 0 & 0 & 0 & 0 & 0 & 0 & 0 & \\
\hline 314 & 3.35 & $\mathbf{S}$ & $\mathbf{D}$ & D & 0 & 2 & 0 & 0 & 0 & 0 & 0 & 0 & 0 & 0 & 0 & 0 & 0 & 0 & \\
\hline 315 & 6.35 & $\mathbf{S}$ & $\mathbf{F}$ & $\mathbf{S}$ & 2 & 0 & 0 & 0 & 1 & 0 & 0 & 0 & 0 & 0 & 0 & 0 & 0 & 0 & \\
\hline 316 & 8.35 & $\mathbf{D}^{*}$ & - & D & 1 & 1 & 2 & 2 & 0 & 0 & 0 & 0 & 0 & 0 & 2 & 3 & 0 & 2 & \\
\hline 317 & 8.35 & $\mathbf{S}$ & $\mathbf{F}$ & $\mathbf{S}$ & 1 & 1 & 0 & 0 & 0 & 0 & 0 & 0 & 0 & 0 & 0 & 0 & 0 & 0 & \\
\hline 318 & 10.35 & D & $\mathbf{F}$ & $\mathbf{F}$ & 1 & 1 & 0 & 1 & 0 & 2 & 0 & 0 & 0 & 0 & 0 & 0 & 1 & 1 & \\
\hline 319 & 10.35 & $D^{*}$ & - & $\mathbf{S}$ & 1 & 1 & 0 & 0 & 1 & 0 & 0 & 0 & 0 & 0 & 0 & 1 & 0 & 0 & \\
\hline 320 & 4.36 & D & $\mathbf{F}$ & $\mathbf{S}$ & 2 & 1 & 0 & 1 & 0 & 0 & 0 & 0 & 0 & 0 & 0 & 0 & 0 & 0 & \\
\hline 321 & 6.36 & D & D & D & 1 & 1 & 0 & 0 & 1 & 0 & 0 & 0 & 0 & 0 & 0 & 0 & 0 & 0 & $\mathrm{Fa} \mathrm{Fa} \mathrm{Fa} \mathrm{L}$ \\
\hline 322 & 7.36 & NI & D & $\mathbf{Y}$ & 3 & 0 & 0 & 0 & 0 & 0 & 0 & 0 & 0 & 0 & 0 & 0 & 0 & 0 & \\
\hline 323 & 10.36 & $\mathbf{S}$ & $\mathbf{D}$ & D & 0 & 2 & 0 & $\begin{array}{l}0 \\
(2 \mathrm{Lu}\end{array}$ & 2 & 0 & 0 & 0 & 0 & 0 & 0 & 0 & 0 & 0 & \\
\hline 324 & 11.36 & $\mathrm{NI}^{*}$ & - & D & 1 & 1 & 0 & $\left\{\begin{array}{l}\text { Pr } 309 \\
\text {. }\end{array}\right.$ & 90 & 0 & 0 & 0 & 0 & 0 & 0 & 0 & 1 & 1 & \\
\hline 325 & 12.36 & $\mathrm{D}^{*}$ & - & $\mathbf{S}$ & 1 & 0 & 0 & 0 & 1 & 0 & 0 & 0 & 0 & 0 & 0 & 0 & 1 & 1 & \\
\hline 326 & 1.37 & D & D & $\mathbf{F}$ & 0 & 1 & 0 & 0 & 1 & 0 & 0 & 0 & 0 & 0 & 0 & 0 & 0 & 0 & $\begin{array}{l}\text { Mo Si Dau LPb } \\
\text { Mo Si Dau P } \\
\text { Fa Lb }\end{array}$ \\
\hline 327 & 2.37 & $\mathbf{D}^{*}$ & - & D & 0 & 1 & 0 & 0 & 1 & 0 & 0 & 0 & 0 & 0 & 1 & 0 & 0 & 0 & \\
\hline 328 & 8.37 & NI & $\mathbf{F}$ & $\mathbf{S}$ & 1 & 1 & 0 & 0 & 1 & 0 & 0 & 0 & 0 & 0 & 0 & 0 & 0 & 0 & \\
\hline 329 & 11.37 & D & D & $\mathbf{D}$ & 0 & $\begin{array}{l}1 \mathrm{I} \\
1\end{array}$ & 0 & 1 & 0 & 0 & 0 & 0 & 0 & 0 & 0 & 0 & 1 & 1 & \\
\hline 330 & 11.37 & $\mathrm{NI}^{*}$ & - & D & 0 & 1 & 0 & 1 & 0 & 0 & $\mathbf{0}$ & 0 & 0 & 0 & 0 & 0 & 0 & 1 & \\
\hline 331 & 11.37 & $\mathrm{D}^{*}$ & - & D & 1 & 2 & 0 & 0 & 0 & 0 & 0 & 0 & 0 & 0 & 0 & 0 & 0 & 0 & \\
\hline 332 & 7.38 & $\mathrm{D}^{*}$ & - & $\mathbf{S}$ & 2 & 1 & 1 & 1 & 0 & 0 & 0 & 0 & 0 & 0 & 2 & 0 & 0 & 0 & \\
\hline 333 & 7.38 & D & D & D & 3 & 0 & 1 & 0 & 0 & 1 & 0 & 0 & 0 & 0 & $\mathbf{0}$ & 0 & 0 & 0 & Fa Bro Lu \\
\hline 334 & 10.38 & $\mathrm{NI}^{*}$ & - & D & 0 & 2 & 0 & 0 & 0 & 0 & 0 & 0 & 0 & 0 & 0 & 0 & 0 & $\mathbf{0}$ & \\
\hline 335 & 12.38 & $\mathrm{D}^{*}$ & - & D & 0 & 1 & 0 & 0 & 1 & 1 & 0 & 0 & 0 & 0 & 0 & 2 & 0 & 1 & \\
\hline 336 & 1.39 & D & $\mathbf{F}$ & $\mathbf{F}$ & 1 & 0 & 0 & 0 & 1 & 0 & 0 & 0 & 0 & 0 & 0 & 0 & 0 & 0 & \\
\hline 337 & 4.39 & $\mathrm{D}^{*}$ & - & D & 3 & 1 & 1 & 0 & 0 & J & 0 & 0 & 0 & 0 & 3 & 0 & 0 & 0 & \\
\hline 338 & 4.39 & NI & $\mathbf{F}$ & $\mathbf{D}$ & 2 & 0 & 2 & 0 & 0 & 1 & 0 & 0 & 0 & 0 & 0 & 0 & 0 & 0 & \\
\hline 339 & 5.39 & D & D & $\mathbf{Y}$ & 2 & 1 & 2 & 0 & 0 & 0 & 0 & 0 & 0 & 0 & 2 & 1 & 0 & 0 & \\
\hline 340 & 7.39 & $\mathbf{N I}^{*}$ & - & $\mathbf{S}$ & 0 & 2 & 1 & 2 & 0 & 1 & 0 & 0 & 0 & 0 & 0 & 3 & 1 & 5 & $\begin{array}{l}\text { Mo Si Lb } \\
\text { Mo Si Lb }\end{array}$ \\
\hline
\end{tabular}

GROUP 11: CLb

\begin{tabular}{|c|c|c|c|c|c|c|c|c|c|c|c|c|c|c|c|c|c|}
\hline 341 & 3.26 & D & $\mathbf{F}$ & $\mathbf{F}$ & 2 & 3 & 0 & 0 & $\left\{\begin{array}{l}\text { Pru } \\
73 \\
3\end{array}\right.$ & $\left\{\begin{array}{l}1 \mathrm{Lu} \\
1\end{array}\right.$ & 0 & 0 & 0 & 0 & 2 & 4 & 1 \\
\hline 342 & 11.29 & D & $\mathbf{F}$ & $\mathbf{S}$ & 1 & 1 & 0 & 0 & 1 & 0 & 0 & 0 & 1 & 0 & 0 & 0 & 0 \\
\hline 343 & 2.30 & D & $\mathbf{F}$ & $\mathbf{S}$ & 1 & 1 & 0 & 0 & 0 & 0 & 0 & 0 & 0 & 0 & 0 & 0 & 0 \\
\hline 344 & 4.30 & $\mathbf{S}$ & D & D & 0 & $i$ & 3 & 0 & 0 & 0 & 0 & 0 & 1 & 0 & 0 & 0 & 0 \\
\hline 345 & 7.30 & $\mathbf{D}^{*}$ & - & $\mathbf{S}$ & 2 & 0 & 2 & 0 & 1 & 0 & 0 & 0 & 0 & 0 & 2 & 2 & 0 \\
\hline 346 & 3.37 & NI & $\mathbf{F}$ & $\mathbf{S}$ & 1 & 3 & 0 & 0 & 1 & 0 & 0 & 0 & 0 & 0 & 0 & 0 & 0 \\
\hline 347 & 3.37 & D & $\mathbf{F}$ & $\mathbf{S}$ & 2 & 1 & 0 & 0 & 0 & 0 & 0 & 0 & 0 & 0 & 0 & 0 & 0 \\
\hline 348 & 11.38 & $\vec{D}$ & D & D & 2 & 1 & 1 & 1 & 1 & 1 & 0 & 0 & 0 & 0 & 0 & 0 & 1 \\
\hline
\end{tabular}

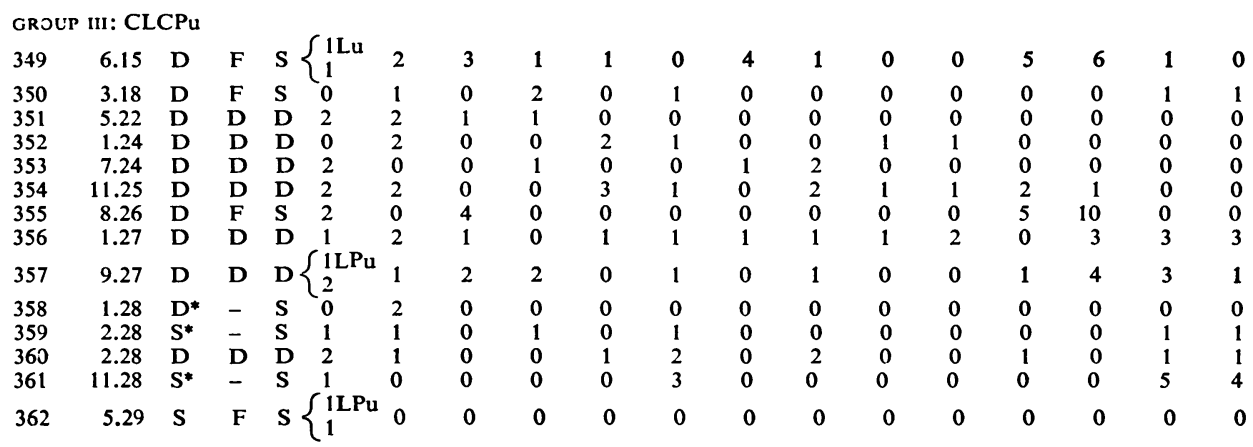




\begin{tabular}{|c|c|c|c|c|c|c|c|c|c|c|c|c|c|c|c|c|c|c|c|}
\hline \multirow[b]{2}{*}{$\begin{array}{l}\text { Serial } \\
\text { No }\end{array}$} & \multirow{2}{*}{$\begin{array}{l}\text { Month } \\
\text { and } \\
\text { year of } \\
\text { birth }\end{array}$} & \multirow{2}{*}{\multicolumn{3}{|c|}{$\begin{array}{l}\text { Method } \\
\text { traced in } \\
1958 / 73 / 78\end{array}$}} & \multicolumn{2}{|c|}{ Children } & \multicolumn{4}{|c|}{ Sibs (excluding twins) } & \multicolumn{4}{|c|}{ Grandchildren } & \multicolumn{4}{|c|}{ Nephews and nieces } & \multirow{2}{*}{$\begin{array}{l}\text { Other affected } \\
\text { relatives } \\
\text { and spouses }\end{array}$} \\
\hline & & & & & Sons & Daus & $\begin{array}{l}\text { Before } \\
\text { Bros }\end{array}$ & Sis & $\begin{array}{l}\text { After } \\
\text { Bros }\end{array}$ & Sis & $\begin{array}{l}\text { Sons } \\
\text { Sons }\end{array}$ & Daus & $\begin{array}{l}\text { Daug } \\
\text { Sons }\end{array}$ & $\begin{array}{l}\text { hters } \\
\text { Daus }\end{array}$ & $\begin{array}{l}\text { Broth } \\
\text { Sons }\end{array}$ & $\begin{array}{l}\text { iss } \\
\text { Daus }\end{array}$ & $\begin{array}{l}\text { Sisters } \\
\text { Sons }\end{array}$ & Daus & \\
\hline 363 & 6.29 & $\mathbf{S}^{*}$ & - & $\mathbf{S}$ & 2 & 1 & 1 & 0 & 3 & 1 & 0 & 0 & 0 & 0 & 3 & 4 & 2 & 1 & \\
\hline 364 & 9.29 & D & D & D & 2 & 4 & 0 & 0 & 0 & 0 & $\mathbf{0}$ & 0 & 0 & 0 & 0 & 0 & 0 & 0 & \\
\hline 365 & 12.29 & $\mathbf{S}$ & $\mathbf{F}$ & $\mathrm{S}$ & $1 \mathrm{LPb}$ & 0 & 0 & 0 & 1 & 1 & 0 & 0 & 0 & 0 & 1 & 0 & 0 & 0 & \\
\hline 366 & 7.30 & $\mathbf{S}$ & $\mathbf{F}$ & $\mathbf{S}$ & 1 & 1 & 0 & 0 & 0 & 0 & 0 & 0 & 0 & 0 & 0 & 0 & 0 & 0 & \\
\hline 367 & 2.31 & NI & $\mathbf{F}$ & $\tilde{S}$ & 1 & 3 & 4 & 5 & 0 & 0 & 0 & 0 & 0 & 0 & 4 & 1 & 4 & 2 & \\
\hline 368 & 4.32 & $\mathbf{D}^{*}$ & - & D & 0 & 1 & 0 & 0 & 1 & 1 & 0 & 0 & 0 & 0 & 1 & 0 & 0 & 0 & \\
\hline 369 & 5.32 & D & D & $\mathbf{Y}$ & 0 & $i$ & 0 & 0 & 0 & 0 & 0 & 0 & 0 & 0 & 0 & 0 & 0 & 0 & \\
\hline 370 & 8.32 & NI & D & $\mathbf{Y}$ & 1 & 2 & 0 & 0 & 1 & 1 & 0 & 0 & 0 & 0 & 0 & 0 & 0 & 0 & \\
\hline 371 & 10.32 & $\mathrm{NI}^{*}$ & - & $\mathbf{S}$ & i & 2 & 0 & 0 & 1 & 5 & 0 & 0 & 0 & 0 & 1 & 2 & 5 & 8 & \\
\hline 372 & 1.33 & D & $\mathbf{F}$ & $\mathrm{F}$ & 0 & 1 & 0 & 0 & 0 & 0 & 0 & 0 & 0 & 0 & 0 & 0 & 0 & 0 & \\
\hline 373 & 5.33 & NI & $\mathbf{F}$ & $\mathbf{S}$ & 0 & 2 & 0 & 1 & 0 & 0 & 0 & 0 & 0 & 0 & 0 & 0 & 2 & 2 & \\
\hline 374 & 6.33 & D & D & $\mathbf{Y}$ & 1 & 3 & 0 & 0 & 0 & 2 & 0 & 0 & 0 & 0 & 0 & 0 & 0 & 1 & \\
\hline 375 & 8.33 & D & D & D & 0 & 4 & 0 & 0 & 0 & 4 & 0 & 0 & 0 & 0 & 0 & 0 & 1 & 0 & \\
\hline 376 & 8.33 & $\overline{\mathbf{D}}$ & D & D & 1 & 1 & 0 & 1 & 0 & 0 & 0 & 0 & 0 & $\mathbf{0}$ & 0 & 0 & 0 & 0 & \\
\hline 377 & 3.34 & $\mathbf{D}$ & $\mathbf{D}$ & $\mathbf{D}$ & $\begin{array}{l}1 L \\
4\end{array}$ & 3 & 0 & 0 & 1 & 2 & 0 & 0 & 0 & 1 & 0 & 0 & 0 & 1 & \\
\hline 378 & 6.34 & $\mathbf{D}$ & D & $\mathbf{S}$ & $\begin{array}{l}4 \\
2\end{array}$ & 0 & 1 & 2 & 0 & 0 & 0 & 0 & 0 & 0 & 0 & 0 & 2 & 3 & \\
\hline 379 & 10.34 & D & $\mathbf{F}$ & $\mathbf{S}$ & 2 & 1 & 2 & 4 & 0 & 0 & 0 & 0 & 0 & 0 & 0 & 0 & 13 & 9 & \\
\hline 380 & 11.34 & $\bar{s}$ & $\mathbf{F}$ & $\mathbf{S}$ & 0 & 2 & 0 & 2 & 0 & 0 & 0 & 0 & 0 & 0 & 0 & 0 & 4 & 1 & \\
\hline 381 & 12.34 & D & $\mathbf{F}$ & $\mathbf{S}$ & 3 & 1 & 0 & 1 & 1 & 0 & 1 & 1 & 2 & 2 & 0 & 0 & 0 & 2 & \\
\hline 382 & 11.35 & $D^{*}$ & - & $\mathbf{S}$ & 3 & 3 & 1 & 3 & 0 & 1 & 1 & 0 & 1 & 0 & 2 & 0 & 6 & 6 & \\
\hline 383 & 12.35 & D & - & $\mathbf{F}$ & 1 & 0 & 1 & 0 & 0 & 0 & 0 & 0 & 0 & 0 & 0 & 1 & 0 & 0 & \\
\hline 384 & 4.36 & D & D & D & 2 & 0 & 2 & 0 & 4 & 0 & 0 & 0 & 0 & 0 & 0 & 0 & 0 & 0 & \\
\hline 385 & 5.36 & D & $\mathbf{F}$ & $\mathbf{S}$ & 0 & 1 & 0 & 1 & 0 & 0 & 0 & 0 & 0 & 2 & 0 & 0 & 0 & 1 & \\
\hline 386 & 9.36 & D & D & D & 2 & 0 & 1 & 0 & 0 & 0 & 0 & 0 & 0 & 0 & 1 & 1 & 0 & 0 & \\
\hline
\end{tabular}

Mo Si L

Fa Bro Son LP

Fa Fa Si LP

$\int F a L P u$

GROUP IV: CLCPb

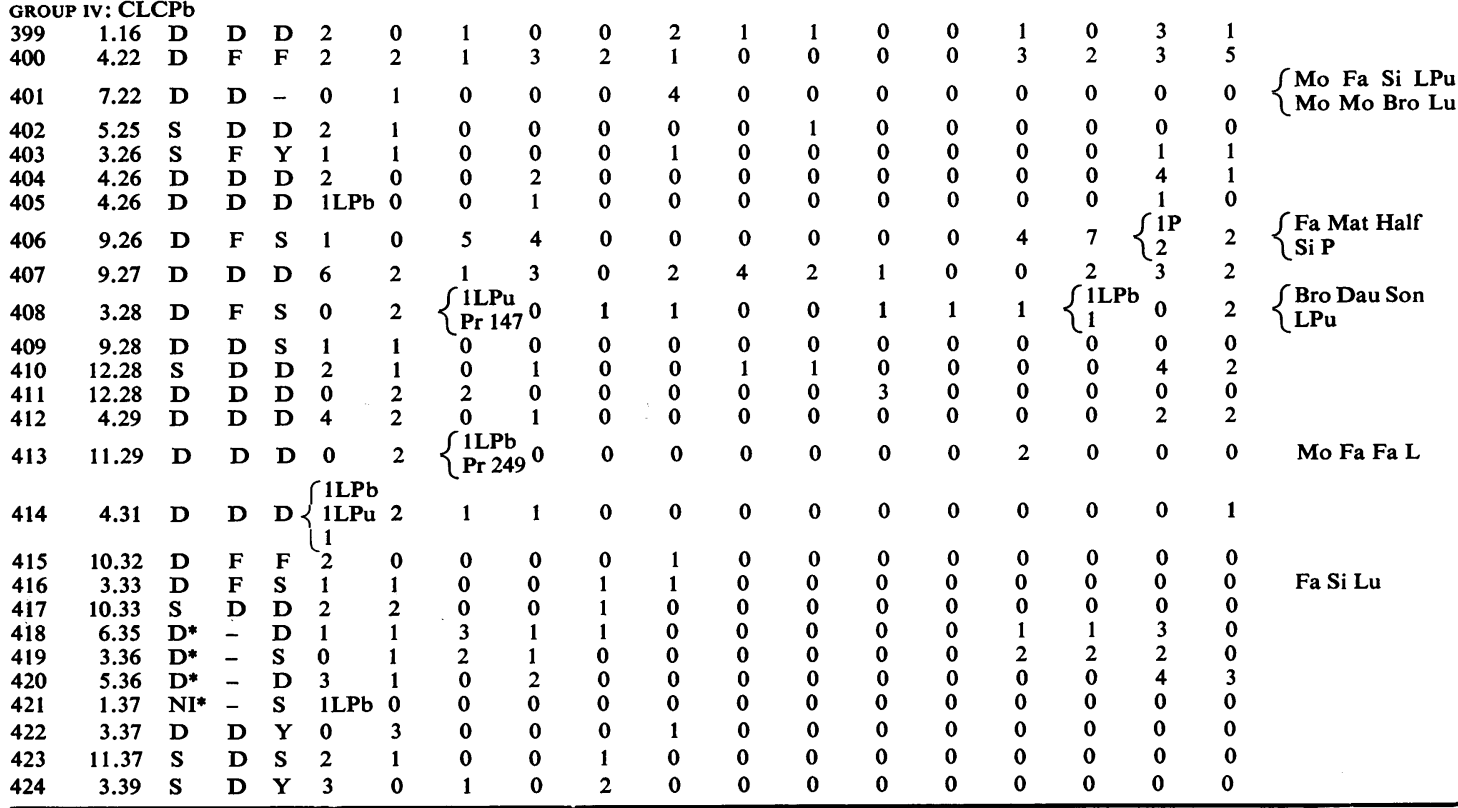

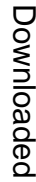




\section{References}

1 Fogh-Andersen P. Inheritance of harelip and cleft palate. Copenhagen: Busck, 1942.

2 Carter CO. Congenital abnormalities. In: Jones FA, ed. Clinical aspects of genetics. London: Pitman, 1961:30-44.

3 Roberts JAF. Inherited diseases. In: Burdette WJ, ed. Methodology in human genetics. San Francisco: HoldenDay, 1962:129-43.

4 Carter CO. Inheritance of common congenital malformations. In: Steinberg AG, Bearn AG, eds. Progress in medical genetics. Vol 4. London: Heinemann, 1965:59-74.

5 Carter CO. Genetics of common disorders. Br Med Bull 1969;25:52-7.

6 Carter CO. Genetics of common single malformations. Br Med Bull 1976;32:21-6.

7 Woolf CM, Woolf RM, Broadbent TR. A genetic study of cleft lip and palate in Utah. Am J Hum Genet 1963;15: 209-15.

8 Woolf CM. Congenital cleft lip. J Med Genet 1971 ;8: 65-83.

9 Czeizel A, Tusnady G. A family study on cleft lip with or without cleft palate and posterior cleft palate in Hungary. Hum Hered 1972;22:405-16.
10 Curtis EJ, Fraser FC, Warburton D. Congenital cleft lip and palate: risk figures for counseling. Am J Dis Child 1961;102:853-7.

11 Bixler D, Fogh-Andersen P, Conneally PM. Incidence of cleft lip and palate in the offspring of cleft parents. Clin Genet $1971 ; 2: 155-9$.

12 Melnick M, Bixler D, Fogh-Andersen P, Conneally PM. Cleft lip \pm cleft palate: an overview of the literature and an analysis of Danish cases born between 1941 and 1968. Am J Med Genet 1980;6:83-97.

13 Koguchi $\mathrm{H}$. Recurrence rate in offspring and siblings of patients with cleft lip and/or cleft palate. Jpn J Hum Genet 1975;20:207-21.

14 Metrakos JD, Metrakos K, Baxter H. Clefts of the lip and palate in twins. Plast Reconstr Surg 1958; 22:109-22.

15 Shields ED, Bixler D, Fogh-Andersen P. Facial clefts in Danish twins. Cleft Palate J 1979;16:1-6.

16 Rank BK, Thomson JA. Cleft lip and palate in Tasmania. Med J Aust 1960;2:681-9.

Requests for reprints to Professor C O Carter, MRC Clinical Genetics Unit, Institute of Child Health, 30 Guilford Street, London WC1N 1EH. 